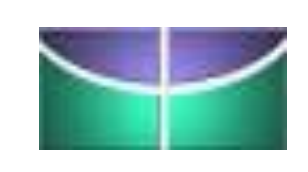

Universidade de Brasília - UnB

DANIELLE DE SOUZA PESSANHA PIMENTEL

Adolescentes em conflito com a lei:

A efetivação da Liberdade Assistida no Distrito Federal

Brasília - DF

2010 
Universidade de Brasília - UnB

DANIELLE DE SOUZA PESSANHA PIMENTEL

\section{Adolescentes em conflito com a lei:}

\section{A efetivação da Liberdade Assistida no Distrito Federal}

Trabalho de Conclusão de Curso apresentado ao Departamento de Serviço Social do Instituto de Ciências Humanas da Universidade de Brasília, como requisito parcial para obtenção do título de bacharel em Serviço Social sob orientação da Professora Ms. Janaína Lopes do Nascimento Duarte.

Brasília - DF

2010 
Universidade de Brasília - UnB

Instituto de Ciências Humanas

Departamento de Serviço Social

Graduação em Serviço Social

\section{Adolescentes em conflito com a lei: A efetivação da Liberdade Assistida no Distrito Federal}

Trabalho de Conclusão de Curso defendido sob a avaliação da Comissão

Examinadora constituída por:

Prof. a Ms Janaína Lopes do Nascimento Duarte

(Orientadora)

Prof. ${ }^{\text {a }}$ Ms Valdenizia Bento Peixoto

Examinadora - Universidade de Brasília - UnB

\section{Perla Ribeiro}

Examinadora - Coordenadora Executiva do Centro de Defesa dos Direitos da Criança e do Adolescente do Distrito Federal- CEDECA/DF

Brasília - DF, 01 de setembro de 2010. 
Dedico este trabalho às minhas avós Celeste e Jurema (in memorian), irmãs, tios e primos por todo o carinho. Aos meus pais e ao meu amor Magno por serem os grandes incentivadores de tudo que realizo. 


\section{AGRADECIMENTOS}

A Deus, que faz com que meus sonhos venham a se concretizar. A Ele, que apesar da grandeza, dá-me a faculdade de pensar e lutar.

Aos meus queridos pais, que, com amor e dedicação me deram subsídios para que eu acreditasse e superasse obstáculos.

Ao meu amor, meu marido que sempre me incentivou e apoiou nos momentos que eram quase "insuportáveis" e sempre compreendeu algumas longas ausências que se dá ao ter que conciliar trabalho e faculdade.

Às minhas amadas irmãs Silvia e Bruna que fizeram parte da minha formação primeira, eternas amigas que me ensinaram a arte da deliciosa e dolorosa convivência humana. Claro, tem também meu cunhado Dudu que virou um irmão por extensão, e com ele compartilho dessa alegria.

Agradeço também à minha amiga Priscila, em que tantos momentos fortaleceume com sua amizade e seu exemplo. Estendo essa gratidão ao seu marido Renato.

Aos professores da Universidade de Brasília que me acompanharam ao longo do curso, especialmente à minhas orientadoras e professoras Janaína e Marcela pela paciência, dedicação e cuidado que tiveram desde os primeiros passos desse sonho até a conclusão.

Ao CEDECA/DF pela oportunidade de aprendizagem no estágio, colaborando muito no processo de reflexão deste trabalho.

Aos amigos do APP-BR (controle de Aproximação de Brasília - CINDACTA I) que sempre me apoiaram e pelo companheirismo que nunca faltou.

A todos os meus amigos da UnB, que deixarão saudades pela amizade, discussões e indagações que tanto colaboraram na minha formação.

Às amadas amigas Tati, Ana Lídia, Vanessa e tantas outras que estão tão longe e sempre tão perto, mas apoiando-me sempre.

A todos que, direta ou indiretamente, contribuíram para o desenvolvimento deste trabalho. 
"Ele é grande, tem ombros de ossos largos, anda um pouco curvo: isso passa, é peso da adolescência. Ele é lento, ele é profundo, ele semeia devagar. Na cara de camponês grosso a profundeza calada de camponês. Ele dormirá bem com uma mulher. Se não se enrolar demais nos largos e fundos meandros de suas pesadas hesitações. Ele é calado, não sabe ainda o que se costuma falar e então diz. (...) Ele é desastrado, quebra coisas sem querer, pede desculpas com um sorriso meio assustado. É preciso ter muita paciência com ele. Tanta paciência. Porque ele pode vir a ser esse silencioso desastrado a vida toda, e não passar disso. É um dos tipos da adolescência mais perigosos: Aquele que muito cedo já é um homem um pouco curvo, e também nele já se sente a grandeza sem palavras."

Clarice Lispector. Um adolescente: C.J. In: A descoberta do mundo. 


\section{RESUMO}

Este trabalho buscou explicar como se dá a efetivação da medida socioeducativa de Liberdade Assistida no Distrito Federal. Os procedimentos metodológicos empregados foram a pesquisa bibliográfica e pesquisa documental, pelos quais se buscou um resgate histórico da trajetória social e das políticas referentes aos direitos da criança e do adolescente, bem como elementos para analisar a execução dessa medida socioeducativa no DF. O resultado da pesquisa revelou que o DF não está conseguindo efetivar essa medida socioeducativa devido ao atual contexto de avanços e retrocessos dos direitos sociais advindos de um processo de Contra-Reforma no Estado Brasileiro, funcional ao avanço do neoliberalismo, fazendo com que se reduzam as despesas com gastos sociais, ocasionando uma descontinuidade e fragmentação na formulação de políticas públicas, além de contribuir para a reiteração do ato infracional e fazer com que a questão social passe a ser objeto intenso de criminalização.

PALAVRAS-CHAVE: Direitos das crianças e adolescentes, Medidas Socioeducativas, Liberdade Assistida, Reforma do Estado. 


\section{LISTA DE ILUSTRAÇÕES, QUADROS E TABELAS}

\section{Figuras}

1. Medidas socioeducativas aplicadas entre os anos 2007 a 2009 no Distrito Federal...49

2. Reiteração do ato infracional.. .51

\section{Quadros}

1. Quadro Comparativo entre a doutrina da situação irregular e doutrina da proteção

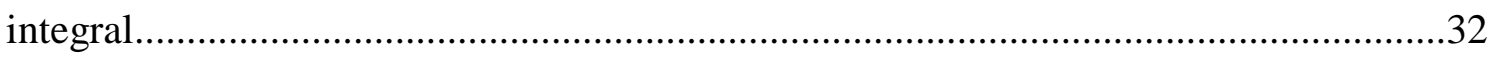

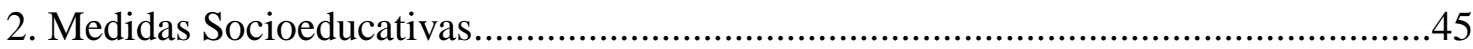

3. Perfil de adolescentes que cumprem medidas socioeducativas em meio aberto no

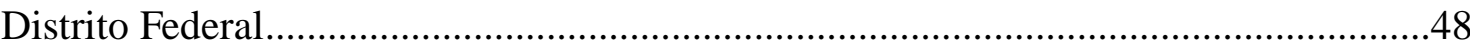

\section{Tabelas}

1. Medida anterior e Reiteração em 2000. .51 


\section{LISTA DE SIGLAS}

CAJE

CBIA

CEDECA

CONANDA

DF

DPCA

ECA

FEBEM

FUNABEM

GDF

LA

LBA

ONGs

ONU

PNBEM

PSC

PSC-C

PSC-D

SAM

SEDEST

SEJUS

SEMSE

SGD

SINASE

VIJ
- Centro de Atendimento Juvenil Especializado

- Centro Brasileiro para a Infância e Adolescência

- Centro de Defesa dos Direitos da Criança e do Adolescente

- Conselho Nacional dos Direitos da Criança e do Adolescente

- Distrito Federal

- Delegacia de Proteção à criança e ao adolescente

- Estatuto da Criança e do Adolescente

- Fundação Estadual do Bem-Estar do Menor

- Fundação Nacional de Bem-Estar do Menor

- Governo do Distrito Federal

- Liberdade Assistida

- Legião Brasileira de Assistência

- Organizações Não- Governamentais

- Organização das Nações Unidas

- Política nacional de Bem-Estar do Menor

- Prestação de Serviços à Comunidade

- Prestação de Serviços à Comunidade-Convênio

- Prestação de Serviços à Comunidade-Doação

- Serviço de Assistência ao Menor

- Secretaria de Estado de Desenvolvimento Social e Transferência de Renda

- Secretaria de Justiça, Direitos Humanos e Cidadania

- Seção de Medidas Socioeducativas

- Sistema de Garantia de Direitos

- Sistema Nacional de Atendimento Socioeducativo

- Vara da Infância e da Juventude 


\section{SUMÁRIO}

INTRODUÇÃO.

CAPÍTULO 1 - TRAJETÓRIA DA INFÂNCIA E ADOLESCÊNCIA NO BRASIL: SIGNIFICADOS E POLÍTICAS SOCIAIS ............................................16

1. O Significado Social da Infância e Adolescência...........................................................16

1.1 Trajeto Histórico-social da Infância e Adolescência..................................................17

1.2. Histórico das políticas públicas para a infância e adolescência..................................27

1.3 Diretrizes das Políticas públicas para a infância a partir do ECA.................................30

CAPÍTULO 2 - POLÍTICAS SOCIAIS PÚBLICAS NO CONTEXTO

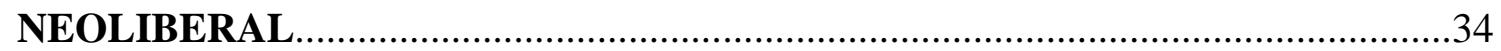

2.1. A contra-reforma do Estado neoliberal e o terceiro setor ............................................35

CAPÍTULO 3 - O ADOLESCENTE AUTOR DE ATO INFRACIONAL NO CUMPRIMENTO DAS MEDIDAS SOCIOEDUCATIVAS.....................................41

3.1. Medidas Socioeducativas aplicáveis ao adolescente autor de ato infracional...........44

3.2. $\mathrm{O}$ adolescente autor de ato infracional no Distrito Federal.......................................... 47

3.3. A Liberdade Assistida-LA....................................................................................52

CAPÍTULO 4 - A LIBERDADE ASSISTIDA NO DISTRITO FEDERAL E OS REFLEXOS DA CONTRA-REFORMA BRASILEIRA.

4.1. O modelo de contra-reforma do Estado nas políticas de atendimento socioeducativo .62

4.2. A reincidência do ato infracional .63

4.3. A punição e repressão ao adolescente como reflexo da ideologia neoliberal.............65

4.4. A questão social presente na prática do ato infracional..............................................67

CONSIDERAÇÕES FINAIS. .69

REFERÊNCIAS BIBLIOGRÁFICAS . .73 


\section{INTRODUÇÃO}

A semântica de origem latina da palavra infância denota algo como ausência de fala, e confirmando essa idéia, vê-se que são praticamente inexistentes relatos da infância contados por ela mesma, sendo em geral, sempre descritos por adultos.

Diversas conotações ao longo dos séculos foram assumidas pela infância e adolescência. Conhecer seu significado social implica não somente compreender os diversos tratamentos dessa parcela populacional nos diferentes momentos e contextos do capitalismo, mas também entender as relações e contradições existentes na forma da sociedade conceber, regular e reconhecer suas necessidades.

Ao estudar a medida socioeducativa de Liberdade Assistida aplicável aos adolescentes em conflito com a lei no Distrito Federal, buscou-se compreender e problematizar as diferentes formas de concepção da infância ao longo da sua trajetória sócio-histórica no capitalismo, uma vez que estas vão interferir diretamente na regulação das políticas para essa parcela da sociedade.

É certo que a efetivação de políticas sociais para a infância e juventude não está imbricada apenas na concepção de infância, mas também nos parâmetros de formação e organização da sociedade capitalista, principalmente a partir do século XIX, com o advento da revolução industrial.

No Brasil, essa situação ocorreu de forma um pouco mais tardia, porém obedeceu aos mesmos parâmetros e critérios mundiais. Atualmente estas políticas sociais são regidas pelo chamado neoliberalismo, que subordina os direitos sociais à lógica orçamentária da política econômica, subvertendo o preceito constitucional (IAMAMOTO, 2001).

Assim, entender o "porquê" da sociedade ter conceituado a infância de distintas formas e efetuado diferentes tipos de políticas no seu enfrentamento, é fundamental no entendimento atual do trato ao adolescente em conflito com a lei.

Isso propicia entender os "clichês" que muitas vezes permanecem, fruto de uma cultura policialesca e repressiva, mas resultado também de uma sociedade que fragmenta as políticas sociais, orientadas por uma racionalidade formal - burguesa, que não contempla a totalidade, mas fragmenta o conhecimento e o trato das expressões da questão social, imbricando-se aí o trato conferido à infância e à adolescência no Brasil. 
É importante ressaltar que a questão social, produzida e reproduzida ampliadamente no capitalismo, tem sido vista enquanto "disfunção" ou "ameaça" à ordem e à coesão social (IAMAMOTO, 2001).

Essa questão social é indissociável do processo de acumulação e dos efeitos que produz sobre o conjunto das classes trabalhadoras, o que se encontra na base da exigência de políticas sociais públicas. Ela ainda, enquanto parte constitutiva das relações sociais capitalistas é apreendida como expressão ampliada das desigualdades sociais. Sua produção e reprodução assumem perfis e expressões historicamente particulares na cena contemporânea.

A particularidade histórica do enfrentamento da questão social retratado aqui é a aplicação da medida Socioeducativa de Liberdade Assistida aos Adolescentes em conflito com a lei através do Sistema Nacional de Atendimento Socioeducativo no Distrito Federal.

Assim, a pergunta de pesquisa "Como o Distrito Federal está efetivando a medida socioeducativa de Liberdade Assistida?" tem por hipótese que a medida socioeducativa de Liberdade Assistida no Distrito Federal aplicável aos adolescentes em conflito com a lei, através da política pública regida pelo Sistema Nacional de Atendimento Socioeducativo - SINASE, não está sendo efetivada de acordo com seus parâmetros regulatórios.

Essa premissa fundamentou-se no conhecimento de que há um contexto de precarização das políticas públicas no Estado capitalista contemporâneo, no qual se acentuam traços de improvisação e inoperância, com funcionamento ambíguo e impotência na universalização do acesso a serviços sociais dela derivados.

Na lógica capitalista atual, as políticas sociais são constantemente fragmentadas, sem regras estáveis, operando em redes obsoletas e deterioradas. Há uma grave regressão dos direitos sociais, que, mesmo reconhecidos constitucionalmente, não vem se constituindo atributo efetivo das políticas sociais no país. Caberia saber se a efetivação da Liberdade Assistida obedecia a essa lógica, ou operava por uma lógica distinta da nossa hipótese.

O interesse por este tema apresenta relação estreita com nossa trajetória acadêmica e pessoal. Durante o curso de Serviço Social na Universidade de Brasília, a formação no campo de estágio direcionou-se para os temas concernentes aos Direitos da 
Criança e do Adolescente. Nossa experiência de estágio supervisionado em Serviço Social realizou-se no Centro de Defesa dos Direitos da Criança e do Adolescente CEDECA/DF, local fértil para o debate e as análises sobre vários aspectos direcionados para a temática da infância e da adolescência.

Dessa forma, a metodologia empregada baseou-se numa perspectiva relacional entre sujeito-objeto, na qual a análise do SINASE no Distrito Federal (DF) estabeleceuse como processo e resultado de relações complexas e contraditórias entre Estado e Sociedade, no âmbito também dos conflitos e lutas de classes na atualidade.

O enfoque metodológico apoiou-se na perspectiva de "situar e analisar os fenômenos sociais em seu complexo e contraditório processo de produção e reprodução, determinado por múltiplas causas na perspectiva de totalidade (...) e inseridos na totalidade concreta: A sociedade burguesa" (BEHRING et BOSCHETTI,2007).

Assim, o caminho escolhido para a análise da Liberdade Assistida no Distrito Federal concebe o real como:

Totalidade concreta, saturada de determinações, mediações e particularidades interconectadas, que entende a realidade social como um processo histórico, desenvolvido fundamentalmente mediante as lutas de classes, portanto, com centralidade na categoria Trabalho e nas contradições entre capital e trabalho como um processo social que tanto tende a reproduzir sua dinâmica e estrutura (positividade) quanto contém sua negação, a possibilidade de Transformação (MONTAÑO, 2008, P.17).

Diante disso, é que se optou por uma abordagem dialética, na qual se propõe “abarcar o sistema de relações que constrói o modo de conhecimento exterior ao sujeito, mas também as representações sociais que traduzem o mundo dos significados". (MINAYO et al, 1994, p.24). Esse processo é, ainda, um contínuo ir-e-vir de um processo para outro - do nível teórico ao empírico, e, deste mais uma vez ao plano teórico que se enriquece sem cessar (SORIANO, 2004, p.30). É por isso que para se analisar a Liberdade Assistida no DF foi necessária toda a compreensão das relações existentes nas transformações dadas pelos sujeitos.

A perspectiva desta pesquisa amparou-se ainda em uma concepção sóciohistórica da realidade social. No estudo da Liberdade Assistida no DF considerou-se explicá-la e compreendê-la com maior profundidade, para que se evitasse uma análise 
superficial ou fragmentada, ou ainda que deixasse de lado seu desenvolvimento e sua transformação.

O método, aqui então empregado, baseado no materialismo histórico e dialético ${ }^{1}$, privilegiou a pesquisa qualitativa, com uma abordagem histórica e social, que, segundo Martinelli (1999), dedica-se à análise dos significados que os indivíduos dão às suas ações. Há ainda, segundo a autora, uma relação dinâmica entre o mundo objetivo e a subjetividade do sujeito. A realidade, assim, é uma construção social que o investigador participa. Os fenômenos estão inter-relacionados e influenciados reciprocamente.

Os procedimentos utilizados basearam-se, principalmente na pesquisa bibliográfica e pesquisa documental, no qual o principal instrumento foi a análise documental.

Além da revisão de literatura pertinente ao conhecimento do tema, a pesquisa bibliográfica baseou-se principalmente em uma pesquisa publicada em 2002, realizada pela Vara da Infância e Juventude do Distrito Federal (VIJ/DF) intitulada "O perfil social dos jovens atendidos pela SEMSE em $2000^{2 \%}$, onde os pesquisadores procuraram analisar o perfil dos adolescentes que cumpriam as medidas socioeducativas em meio aberto no Distrito Federal entre os anos de 1999 e 2000.

A análise documental realizada por este trabalho privilegiou uma análise dos documentos e relatórios disponibilizados pela própria VIJ/DF nos anos 2007 a 2009, no qual estão contidos dados como renda, sexo, escolaridade e outros que permitiram traçar o perfil social dos adolescentes que cumprem a medida socioeducativa de Liberdade Assistida. Reportagens da impressa escrita e virtual foram também utilizadas para subsidiar esta pesquisa.

A relevância deste estudo encontra-se na possibilidade de entender e fazer a crítica à efetivação das políticas públicas de atendimento ao adolescente em conflito com a lei, particularmente a medida socioeducativa de Liberdade Assistida, na perspectiva da articulação com outras políticas, não se restringindo ao simples acompanhamento do adolescente.

\footnotetext{
${ }^{1}$ Soriano (2004) considera que no materialismo histórico-dialético, os fenômenos não são estáticos, mas sujeitos a contínuas mudanças em diversas direções. A realidade é um processo, e não um conjunto de coisas prontas. O motor do desenvolvimento é a existência de pólos antagônicos que se encontram em unidade relativa e em luta permanente.

${ }^{2}$ SEMSE - Seção de Medidas Socioeducativas
} 
Além disso, a Liberdade Assistida é, segundo Saraiva (1998), considerada como "medida de ouro", haja vista os elevados índices de sucesso alcançados com esta medida, desde que adequadamente executada. Outros autores também concordam que esta é uma medida muito eficiente, mas há também há um consenso de que sua aplicação é difícil, uma vez que depende de aparelhos bem estruturados para ser efetivada conforme preconizada no ECA.

Diante do exposto, o trabalho encontra-se organizado em quatro capítulos. $\mathrm{O}$ primeiro capítulo fez uma busca em torno da trajetória sócio-histórica da infância no Brasil, onde a infância e adolescência foram retratadas dentro dos principais contextos das sociedades brasileiras.

O segundo capítulo procurou analisar as políticas sociais públicas no atual contexto de contra-reforma do Estado neoliberal e suas implicações na política de atendimento à infância e adolescência.

O terceiro capítulo debruçou-se em analisar os documentos e relatórios, bem como a pesquisa realizada sobre a aplicação das medidas socioeducativas no DF, articulando com a conjuntura neoliberal de retrocesso social.

Já o quarto capítulo buscou relacionar a desfragmentação e não-efetivação da Liberdade Assistida como parte integrante da ideologia neoliberal aplicada aos adolescentes em conflito com a lei.

Esperou-se com esta contribuição teórica analisar o tema, não apenas na perspectiva de sistematizar uma realidade, mas também na de produzir conhecimentos que visem à garantia de direitos de crianças e adolescentes brasileiras. 


\section{CAPÍTULO 1}

\section{TRAJETÓRIA DA INFÂNCIA E ADOLESCÊNCIA NO BRASIL: SIGNIFICADOS E POLÍTICAS SOCIAIS}

\section{O significado social da infância e da adolescência}

Compreender a trajetória histórica e social infanto-juvenil no Brasil implica situá-la no marco das relações sociais, políticas e econômicas do modo de produção capitalista.

A história da sociedade brasileira está permeada de situações nas quais um ou mais aspectos importantes da questão social estão presentes. A questão social que se fala aqui diz respeito ao "conjunto das expressões das desigualdades sociais engendradas na sociedade capitalista madura, impensáveis sem a intermediação do Estado" ${ }^{3}$ (IAMAMOTO, 2001, p.17).

A Questão Social, portanto, expressa disparidades econômicas, políticas e culturais das classes sociais, colocando em evidência relações e interesses diversos, pelos quais o Estado atende demandas de uma classe dominante, mas também incorpora demandas das classes trabalhadoras, sendo obrigado a reconhecer e enfrentar a Questão Social como política.

Envolve por isso, uma luta pela cidadania, expressando a consciência e a luta pelo reconhecimento dos direitos sociais e políticos de todos os indivíduos sociais. ${ }^{4}$

Como ponto de partida para a compreensão da história social da infância e da adolescência, é necessário considerar que a questão social se expressa pelo fato de que as políticas sociais são, na verdade, respostas às várias expressões da questão social no capitalismo, cujo fundamento se encontra nas relações de exploração do capital sobre o

\footnotetext{
${ }^{3}$ Sobre a questão social Iamamoto (2001, p.17) afirma que sua gênese encontra-se no caráter coletivo da produção, contraposto à apropriação privada da própria atividade humana - o trabalho - das condições necessárias à sua realização, assim como de seus frutos. É indissociável da emergência do "trabalhador livre", que depende da venda de sua força de trabalho com meio de suas necessidades vitais.

${ }^{4}$ Ainda Segundo Iamamoto (2001, p.17) "foram as lutas sociais que romperam o domínio privado nas relações entre capital e trabalho, extrapolando a questão social para a esfera pública, exigindo a interferência do Estado para o reconhecimento e a legalização de direitos e deveres dos sujeitos sociais envolvidos".
} 
trabalho. A questão social se expressa em suas refrações, e, por outro lado, os sujeitos históricos engendram formas de seu enfrentamento.

Uma refração dessa questão social situa-se na Infância e Adolescência, no qual segundo Irene Rizzini (2009), se dá principalmente na infância e adolescência pobres, que sempre permaneceram à margem da sociedade por não estarem afinados com a ética capitalista do trabalho que dividia os pobres em "bons" e "vagabundos", retratando a ideologia das classes dominantes: aqueles trabalhadores que eram induzidos a aceitar qualquer trabalho a qualquer preço, eram os chamados "bons"; já os "vagabundos", eram aqueles que não aceitavam tal tipo de trabalho.

Essa concepção acrítica e preconceituosa da pobreza, incluindo aí a sua infância, contribuiu para perpetuar as desigualdades sociais. Nesse contexto, estão inseridos os adolescentes autores de ato infracional.

Com o objetivo de situar os principais marcos referentes à infância e adolescência no Brasil, buscou-se nesse trabalho uma articulação da história da infância e adolescência com os principais contextos sócio-históricos brasileiros.

\subsection{Trajeto Histórico-social da Infância e Adolescência}

No Brasil - Colônia, as ordenações do Reino tiveram larga aplicação. O pai era a autoridade máxima familiar. Contudo, como os índios que aqui viviam tinham costumes diferenciados, os Jesuítas educavam as crianças como forma de catequizar também os pais. Na visão dos jesuítas, a criança era percebida como um "papel blanco", "tábula rasa", onde poderia ser moldada segundo os costumes ocidentais (PRIORE, 1991).

O processo de colonização brasileiro serviu à acumulação originária de capital nos países centrais, mas sob o "peso do escravismo" (IANNI, 1989 apud BEHRING et BOSCHETTI,2007), trazendo consigo a idéia de desqualificação, a qual é definidora da relação capital e trabalho no país.

As crianças escravas eram consideradas propriedade individual do seu dono, servindo como patrimônio e mão- de- obra, podendo este ser considerado um marco do trabalho exploratório infantil no Brasil. ${ }^{5}$

\footnotetext{
${ }^{5}$ Nesse período, as crianças morriam com facilidade, e as crianças escravas serviam ainda como brinquedo dos filhos dos senhores e divertimento das visitas, sendo por vezes consideradas como animaizinhos de estimação, sofrendo humilhações, maus-tratos e até mesmo exploração sexual. Segundo
} 
Nesse período, o abandono de crianças, escravas ou não, era uma prática bastante freqüente até meados do século XIX. A assistência às crianças abandonadas, órfãs e pobres seguiu os moldes ditados pela Corte Portuguesa, cabendo às Câmaras Municipais, desde 1521, cuidar das crianças abandonadas, mas essa assistência foi assumida, em grande parte, pelas conhecidas popularmente Santa Casa da Misericórdia ou Santa Casa.

Evidencia-se nesse atendimento uma articulação do público com o privado no tratamento com as questões infanto-juvenil. Tal processo figurará também nos moldes contemporâneos de definição de políticas para a infância e adolescência pobres, no qual a capacidade de uso dos recursos públicos está em constante interação com agentes privados, com interesses particulares, pessoais, religiosos, morais, econômicos, e políticos.

Abolida a escravatura, verifica-se um período de grandes transformações políticas, econômicas e sociais no país. A questão social nesse contexto situou-se no embate político determinado pelas contradições entre capital e trabalho e entre forças produtivas e relações de produção, gerando desigualdades, pobreza, desemprego e necessidades sociais.

O que fazer então com essa grande quantidade de pessoas afastadas das forças produtivas? A mentalidade da época concebeu que a resolução do problema era fazer trabalhar o homem "livre", fosse ele ex-escravo ou imigrante. Irene Rizzini (2008) afirma que havia certo consenso de que a Abolição acarretaria inevitavelmente a desordem.

A ética do trabalho, assim, emerge como um objetivo comum (RIZZINI, 2008). Criou-se o combate a um estilo de "vida vagabunda" que era identificado como ato de insubordinação. O indivíduo que, embora apto, recusava-se a trabalhar, ou seja, aos que iam contra a lógica dominante, eram tidos por pessoas não-patriotas, ou até mesmo "vagabundos".

Assim, com o advento do liberalismo, na fase industrial do capitalismo, ocorreu o princípio do trabalho como mercadoria e sua regulação pelo livre mercado. Nessa

Rizzini (2009), mesmo depois da Lei do Ventre Livre, em 1871, a criança escrava podia ser mantida nas mãos dos senhores até os 14 anos para ressarcir dos seus gastos com ela, seja mediante o seu trabalho gratuito até os 21 anos, seja entregando-a ao Estado, mediante indenização. 
fase, a partir de meados do século XIX, houve grande demanda da força de trabalho nas fábricas, na qual mulheres e crianças foram incorporadas recebendo salários baixíssimos. Crianças e Adolescentes cumpriam carga horária semelhante a dos adultos.

O Estado exercia um papel de "mal necessário", devendo ser mínimo, no sentido de se restringir a fornecer a base legal com a qual o mercado poderia maximizar os "benefícios aos homens", ou seja, a garantir a liberdade individual, a propriedade privada e assegurar o livre mercado (BEHRING et BOSCHETTI,2007).

O mercado deveria surgir como um mecanismo natural das regulações sociais. Nessa ótica, a miséria passou a ser compreendida como resultado da capacidade humana de adquirir riquezas, e não como resultado de acesso desigual da riqueza. Nesse sentido, ao Estado cabia apenas assegurar a assistência mínima a esses segmentos como um paliativo, a caridade privada responsabilizava-se pelas demais demandas.

No Brasil, o liberalismo só é mesmo impulsionado com a criação do Estado Nacional, o que acarretou, por um lado, desejo de ruptura com o passado colonizado. Porém, essa independência não era um desejo da sociedade geral, servia apenas para atender o patrocínio dos interesses gerais das classes dominantes.

Nesse contexto de fortalecimento do Estado Nacional, a criança passa a ser percebida como valioso patrimônio de uma nação; como "chave para o futuro", um ser em formação que tanto poderia ser transformado em "homem de bem" ou degenerado (RIZZINI, 2008). Sua classificação dava-se de acordo com sua origem familiar e sua "herança" social. Os "bem nascidos" podiam ser crianças e viver sua infância; os demais estavam sujeitos ao aparato jurídico-assistencial destinado a educá-los ou corrigi-los, vistos como "menores abandonados ou delinqüentes".

Estava implícita a idéia de periculosidade, carregada de ambigüidades: 1) a criança personificava o perigo, representando a ameaça propriamente; ou 2) era representada como potencialmente perigosa, em perigo de o ser.

A criança que mais aparecia na literatura da época era aquela que, aos olhos da elite, carecia da "proteção" do Estado, como forma de ajustamento à lógica dominante. Para isso, ela precisava ser corrigida ou reeducada.

Nesse período estabeleceu-se uma correlação de forças entre as instâncias jurídicas e médicas, na qual médicos e juristas buscavam produzir novos saberes 
condizentes com a importância da infância para o ideal de nação civilizada que se almejava.

Nesse aspecto, o interesse à criança e ao adolescente aparece em torno da primeira lei penal do Império, o Código Criminal de 1830, no qual os menores de 14 anos não seriam julgados criminosos, salvo se constatado que a criança agiu com discernimento para o crime. Cabe ressaltar que a infância teve ingresso no Direito através de "atos de delinqüência" 6 .

Já na área médica, marca-se a difusão do movimento higienista. A higiene passa a ser a condição "sine qua non" de poder, progresso e de civilização (RIZZINI, 2008). Nesse sentido, a missão era sanear a sociedade originando expressiva produção de conhecimentos especializados sobre a infância, bem como a penetração da prática médica no âmbito doméstico. A família era o alvo privilegiado dos higienistas, pois era preciso sanear a sociedade como um todo, e a criança era uma ponte direta de acesso à família.

Surgiu naquele período uma categoria a qual chamavam de "viciosos" que, na opinião da época, eram aqueles que já haviam se entregado ao hábito do vício e permaneciam no ócio; recusando-se a observar os "termos do bem viver" na sociedade. "Eram avessos ao trabalho, abandonavam os filhos à própria sorte, eram libertinos e arredios aos princípios religiosos" (RIZZINI, 2008, p.68). Segundo Rizzini (2008, p.69):

Percebidos na sociedade da época como "contaminados" por uma pobreza indigna, eram os viciosos o principal alvo de intervenção social, no início do século XX no Brasil, por dois motivos específicos: primeiro porque representavam um perigo que tinha que ser erradicado e, segundo, porque, seus filhos precisavam ser salvos da influência perniciosa que os envolvia, a fim de que pudessem seguir o caminho do trabalho e da virtude, tornando-se úteis ao país, em oposição ao caminho inexorável da degradação e da criminalidade que os esperava.

Criou-se, assim, um estereótipo em torno do fenômeno da vadiagem. "Para que se garantisse a paz social e o progresso da nação, seria preciso estabelecer a ordem, educar e moralizar a população - a começar pela infância - futuro da nação" (RIZZINI, 2008, p.76).

\footnotetext{
${ }^{6}$ O conteúdo claramente punitivo das legislações jurídicas só modificou-se substancialmente em 1990 com a aprovação do Estatuto da Criança e do Adolescente.
} 
A noção de pecado é substituída pela de vício, algo que, segundo o pensamento da época, podia ser adquirido, mas também evitado ou corrigido.

Era para a infância exposta ao vício e ao crime, e que aos olhos da classe dominante da época era 'moralmente abandonada' que se voltavam os olhares preocupados em busca de solução, pois não se cogitava duvidar da ameaça que representava (RIZZINI, 2008). Será especialmente para esse segmento da população infantil que a sociedade defenderá a intervenção dos poderes públicos com a máxima urgência nas primeiras décadas republicanas.

Nesse ínterim, a criança passa a representar uma ameaça às elites da sociedade brasileira nunca antes descrita com tanta clareza. Põe-se em dúvida sua inocência. Descobrem-se na "alma infantil" elementos de crueldade e perversão, devendo por isso, serem afastadas do caminho que conduz a criminalidade e dos ambientes considerados viciosos, sobretudo as ruas e as casas de detenção.

Assim, ao final do séc. XIX identifica-se a criança, filha da pobreza materialmente e moralmente abandonada - como um problema social gravíssimo, pois nas palavras de Behring e Boschetti (2007) o liberalismo no Brasil não comportava a questão dos direitos sociais, começando essa situação a se alterar substancialmente a partir dos anos 1930, período pós Grande-Depressão.

Do referencial jurídico claramente associado ao problema, constrói-se uma categoria específica - a do "menor" 7 - que, segundo Tôrres et al (2006), constitui-se enquanto categoria que define crianças e adolescentes pobres das cidades que, por não se encontrarem sob a autoridade dos pais, eram consideradas abandonadas.

Irene Rizzini (2009) afirma que o "problema da criança" começa a adquirir uma dimensão política, no que muitos chamavam de "ideal republicano" na época. A autora afirma ainda que não se tratava de ressaltar apenas a importância, mas sim a urgência de se intervir, educando ou corrigindo os "menores" para que estes se transformassem em indivíduos úteis e produtivos para o país, assegurando a organização moral da sociedade.

\footnotetext{
${ }^{7}$ Esse termo será empregado ao longo do trabalho entre aspas porque historicamente revestiu-se de um sentido pejorativo para designar crianças e adolescentes a partir de suas necessidades ou comportamento (menor infrator, menor carente, menor abandonado). O conceito atualmente é inapropriado e foi superado pela atual legislação nacional e internacional em relação aos direitos da criança e do adolescente, por ser discriminatório, pejorativo e dirigido apenas a crianças e adolescentes das classes mais pauperizadas tais como pobres, negros, em situação de rua, que cometem atos infracionais, dentre outros.
} 
Criou-se, assim, em 1927, o Código de Menores, denominado Código Mello Mattos $^{8}$. Este Código considerava a família responsável pelo desvio de conduta de seus filhos. Nele, a palavra "menor" se consolida como classificatória da infância pobre e, contraditoriamente, é também a partir dele que começam a ser formuladas estratégias relativas à intervenção junto a crianças e adolescentes (TÔRRES et al, 2006) .

Este Código baseava-se na "Doutrina da Situação Irregular", a qual considerava os "menores" como objeto de medidas judiciais quando encontrados privados de condições necessárias essenciais à sua subsistência, saúde e instrução obrigatória, e também quando vítimas de maus tratos, em perigo moral, com desvio de conduta e como autores de ato infracional. Crianças e adolescentes eram levados para os tribunais independentemente de sua situação estar vinculada a uma questão social ou a uma questão judicial de conflito com a lei.

A manifestação da Questão Social na criança e no adolescente é então reconhecida como questão política, sendo necessária uma intervenção estatal para não abalar a hegemonia da classe dominante.

A esfera judiciária protagonizou a formulação e busca de soluções para o problema da infância tornando-a, efetivamente, objeto de sua alçada jurídica.

Tôrres et al (2006) afirma que, nesse aspecto, Justiça e Assistência formavam, assim, um primeiro conjunto de estabelecimentos oficiais de proteção aos "desamparados" e "delinqüentes". Começam a surgir as categorias de prevenção, educação, recuperação e repressão aos "menores", a fim de que eles se transformassem em indivíduos úteis e produtivos para o país, assegurando a organização moral da sociedade.

Contudo, é somente a partir dos anos 30, do século XX, que a assistência passa a ser paulatinamente absorvida pelo Estado, passando a haver uma generalização das políticas sociais devido à crise capitalista compreendida nos períodos de 1929 a $1932^{9}$, e cuja intensidade produziria mudanças significativas no mundo do capital.

\footnotetext{
${ }^{8}$ Este código incorporava também a visão higienista de proteção do meio e do indivíduo, e a visão jurídica repressiva e moralista em defesa de bons costumes e da honra

${ }^{9}$ A Crise de 1929 foi uma grande depressão econômica que teve início no mesmo ano, e que persistiu ao longo da década de 1930, terminando apenas com a Segunda Guerra Mundial. Este período causou altas taxas de desemprego, quedas do produto interno bruto de diversos países, bem como na produção industrial e nos preços de ações em diversos países no mundo. Para entender o assunto, cf. BEHRIN, Elaine Rossetti e BOSCHETTI, Ivanete. In: Política Social. Fundamentos e história. Cortez Editora.São Paulo, 2007, p.67-71.
} 
Antes disso, a política de proteção à infância, atrelada à assistência social possuía, por característica, relações travestidas da chamada filantropia (TÔRRES et al, 1998), a qual substituindo a caridade, reservava-se a missão de prestar assistência aos pobres desvalidos, em associação às ações públicas. A filantropia distinguia-se da caridade pelos seus métodos, considerados científicos, por esperar resultados concretos e imediatos, como o bom encaminhamento dos desviantes à vida social (RIZZINI, Irma, 2009).

Nesse contexto brasileiro, o Capitalismo concorrencial dá passagem ao capitalismo monopolista ${ }^{10}$. Netto (2005) enfatiza que a constituição desta organização objetivava a urgência de viabilizar o acréscimo dos lucros capitalistas através dos controles dos mercados.

Após a chamada revolução de 1930, o Estado Varguista ao consolidar a ordem capitalista no Brasil, através do aparelho repressor para controlar tensões sociais, e reconhecendo a questão social como uma questão política, viabilizou seu projeto de modernização amparado na ordem capitalista.

O governo Vargas (1930-1945) expressava as grandes preocupações das elites da época com relação à assistência à infância, tais como a utilização de critérios científicos no atendimento, a aliança entre os setores públicos e privados, a defesa da nacionalidade, a mortalidade infantil das cidades brasileiras e a formação de uma raça sadia, de cidadãos úteis.

Dessa forma, a compreensão da infância "abandonada e delinqüente" do ponto de vista da moral, já não era mais suficiente. Passaram-se, então, a recorrer, com maior freqüência ao entendimento científico da questão, onde ampliaram o leque de conhecimento desse campo, colaborando até no desenvolvimento de novas disciplinas, o que culminou no entendimento de não somente serem os "maus costumes" a razão de um comportamento desviante, mas também outros fatores como distúrbios psíquicos e físicos, hereditariedade, urbanismo, industrialismo, pauperismo, dentre outros.

Nesse período, destaca-se também a proteção dada à família e a criança das classes pauperizadas, passando estes a ser alvo de inúmeras ações do governo,

\footnotetext{
${ }^{10}$ No capitalismo monopolista cresce a tendência a economizar trabalho "vivo", com a introdução de novas tecnologias, fazendo aumentar a taxa de afluência de trabalhadores no exército industrial de reserva, acarretando como consequiência o aumento do desemprego (Behring et Boschetti, 2007).
} 
inaugurando uma política de proteção materno-infantil. Havia uma suspeita de que a delinqüência era causada pelo abandono.

Um grande contingente de mulheres lançou-se no mercado de trabalho. Assim, Estado e sociedade uniram-se para manter a estabilidade da família e garantir a adequada educação da criança com a finalidade de formar o trabalhador como "capital humano" do país, através do preparo profissional e respeito à hierarquia pela educação moral.

Na segunda metade dos anos 1960, período marcado por regimes ditatoriais, a existência de uma questão social tornou-se incontestável (VOGEL, 2009). O golpe de 1964 instaurou uma ditadura que durou 20 anos e impulsionou um novo momento de modernização conservadora no Brasil, com importantes conseqüências para a política Social como um todo, e também para a infância e adolescência.

O Brasil pós-64 vive a expansão de um "fordismo à brasileira" ${ }^{11}$, por meio do chamado Milagre Brasileiro, onde o grande crescimento econômico é fruto de uma intensa internacionalização da economia, aproveitando-se da necessidade do capital restaurar as taxas de crescimento dos esgotados "anos de ouro". ${ }^{12}$ A economia brasileira cresceu a taxas de $11 \%$ a $14 \%$.

A ditadura reconfigurou, nesse processo, a questão social, que passa a ser enfrentada numa combinação de repressão e assistência, tendo em vista manter sob controle as forças do trabalho que despontavam. Nesse quadro, houve um forte incremento na política social brasileira, para buscar adesão e legitimidade das classes trabalhadoras, visto haver um período de perda das liberdades democráticas para os discordantes dessa gestão ditatorial (BOSCHETTI et BEHRING, 2007).

As mudanças sociais, em ritmo acelerado, impulsionavam um avassalador processo de urbanização. Contudo, a ditadura militar abria espaços para a saúde, a previdência e a educação privadas, configurando um sistema dual de acesso às políticas sociais: para quem pode e para quem não pode pagar.

\footnotetext{
${ }^{11}$ Fordismo/keynesianismo foi um período inaugurado a partir da $2^{\text {a }}$ Guerra mundial motivado também pela crise de 1929. Seu principal fator decisivo foi a intervenção do Estado nas relações sociais e econômicas.

${ }^{12}$ Boschetti e Behring (2007, p.103) defendem que o Fordismo/keynesianismo foi marcado por um período de expansão do capital, chamado "anos de ouro". Contudo, ao final dos anos 1960, esses anos de capitalismo regulado pelo Estado através de funções mediadoras civilizadoras cada vez mais amplas, a absorção de novas gerações no mercado de trabalho, restrito já naquele momento pelas tecnologias poupadoras de mão-de-obra, não são as mesmas, contrariando as expectativas de pleno emprego, base fundamental daquela experiência.
} 
Outra herança é que, mesmo com uma ampliação dos serviços públicos e privados, milhões de pessoas permaneciam fora do complexo assistencial - industrial tecnocrático - militar. Com isso, progredia-se a situação de baixa renda, com pouca participação no consumo de bens culturais e materiais, o que foi concebido como um "processo de marginalização".

A assistência à infância no governo militar via na questão social, e no seio desta, o problema do "menor". Assistir a este segmento populacional constituiu-se numa estratégia para resolver o que se considerava um problema de "segurança nacional". Em defesa dessa segurança justificou-se, a prática de internação.

A intervenção desses governos culminou na criação de políticas que tinham também a missão de velar para que os "menores abandonados" não viessem a transformar-se em presa fácil do comunismo e das drogas, tendo assim o controle autoritário e centralizado na implementação da assistência aos "menores" enquanto problema social.

Um novo Código de Menores, instaurado em 1979, criou a categoria de "menor em situação irregular”, que não muito diferente da concepção vigente no antigo Código de 1927, expunha as famílias populares à intervenção do Estado, por sua condição de pobreza. A situação irregular era caracterizada pelas condições de vida das camadas pauperizadas da população

Com a sinalização e esgotamento dos projetos de crescimento dos governos militares, há uma lenta e gradual abertura, num processo de transição para a democracia, mas ainda em muitos aspectos fortemente controlada pelas elites para evitar a constituição de uma vontade popular radicalizada.

Em 1984, o país estava às vésperas da concretização da abertura democrática. Os amplos poderes mantidos aos magistrados não demoraram a ser questionados e combatidos pelos movimentos sociais, com a transição democrática.

Diante desse quadro e graças às possibilidades de organização e participação populares na luta pela garantia de direitos, novos atores políticos ${ }^{13}$ entraram em cena.

\footnotetext{
${ }^{13}$ Esses atores políticos, embora não sendo homogêneos, e estando também num campo permanente de disputa de interesses de classes, desencadearam um processo de reivindicação dos direitos de cidadania para crianças e adolescentes. Dentre estes, destacam-se o Movimento Nacional de Meninos e Meninas de Rua (MNMMR), Pastoral da Criança, UNICEF (Fundo das Nações Unidas para a Infância), dentre outros.
} 
A abertura política do regime militar propiciou a visibilidade da luta dos movimentos sociais em defesa do sujeito da criança e do adolescente em situação de pobreza e marginalidade social.

Essa transição democrática brasileira, engendradas na industrialização e urbanização, criou condições para o surgimento de um movimento operário popular e novo, o que foi decisivo para uma espécie de refundação da esquerda brasileira.

Assim, em 1986, o cenário político brasileiro é estremecido com a Convocação da Assembléia Nacional Constituinte para a elaboração de uma nova Carta Constitucional para o país. O texto constitucional refletia a disputa de hegemonia, contemplando avanços em direção a um Estado Social em alguns aspectos, a exemplo dos direitos sociais, com destaque para a seguridade social, os direitos humanos e políticos, com fortes mobilizações sociais.

Diversos projetos criticavam a política oficial de atendimento, desenvolvendo ações pautadas no respeito aos meninos/as, valorização de suas potencialidades, atendimento em meio aberto e concebendo as crianças e adolescentes como sujeitos do processo histórico e pedagógico.

No Plano Internacional há também uma forte tendência de proteção aos direitos da Criança e do Adolescente. Todo esse movimento conseguiu inscrever sua proposta na Constituição de 1988, sob a forma do artigo 227, que manda assegurar, com absoluta prioridade, os direitos das crianças e dos adolescentes, incumbindo desse dever a família, a sociedade e o Estado, aos quais cabe, igualmente, protegê-los contra qualquer forma de abuso.

Desse processo, resultou o Estatuto da Criança e do Adolescente (ECA), e, com ele, um novo paradigma jurídico, político e administrativo, destinado à compreensão e resolução da problemática da infância e da juventude no Brasil.

O Estatuto dirige-se não mais aos "menores moralmente e materialmente abandonados ou delinqüentes", passíveis de intervenção e políticas repressivas do Estado, mas a todas as crianças e adolescentes, reconhecidos como "sujeito de direitos". Inaugura-se assim, uma nova concepção aos atendimentos para as políticas de atendimento à infância e adolescência, cuja efetivação, a partir do ECA, vai esbarrar em uma contraditória convivência entre universalidade e seletividade, em face de um novo processo histórico que será analisado com mais afinco no capítulo 2 deste trabalho. 


\subsection{Histórico das políticas públicas para a infância e adolescência}

A elaboração do Estatuto da Criança e do adolescente constituiu-se em um marco jurídico-político de fundamental importância no campo da infância e juventude brasileira. Antes da sua aprovação, em 1990, a questão da infância e da adolescência foi acompanhada e proposta por uma intricada rede de assistência provida por setores públicos e privados da sociedade. Nesse processo, verifica-se que o recolhimento de crianças às instituições de reclusão foi o principal instrumento de assistência à infância no Brasil (RIZZINI, 2004).

As políticas públicas voltadas para a infância, no sentido em que comumente são definidas, só tiveram lugar no Brasil a partir da República (ARANTES, 2009). Contudo, verifica-se a persistente cultura de política asilar e de contenção de ameaças, institucionalizando crianças e adolescentes, como forma de controlar as classes mais pauperizadas.

A Lei do Código Criminal de 1830, por exemplo, estabelecia a responsabilidade penal para 14 anos aos adolescentes que tivessem cometido crimes, devendo estes ser recolhidos às chamadas Casas de Correção.

Irene Rizzini (2009) aponta ser surpreendente para a época um recolhimento de adolescentes em estabelecimentos especiais que visasse sua correção, pois não estava ainda em voga a discussão sobre a prevalência da educação sobre a punição, o que veio a ocorrer somente no final do século XIX.

No Regime Republicano, o Brasil já possuía uma vasta experiência à infância desvalida, intimamente relacionada à educação e à instrução populares. Contudo, a assistência pública nesse período foi qualificada pelos críticos da época como uma espécie de "caridade oficial", por não ter uma orientação unificada, ou seja, uma centralização, e nem seguir os moldes preconizados pelo avanço da ciência (RIZZINI et RIZZINI, 2004).

Nesse período, a movimentação em torno da elaboração de leis para a proteção à infância é intensa, culminando na criação de um Juízo de Menores, no Rio de Janeiro.

Pouco tempo depois foram criadas instituições para recolhimento dos indesejados das cidades, na qual o governo autorizou a fundar as chamadas "colônias 
correcionais" ${ }^{14}$, que, instaladas isoladamente, atendiam a finalidade de sanear a cidade, e também de resolver o problema da "vadiagem" através da "correção pelo trabalho". Nestas colônias, ficavam também os "menores viciosos", no qual a orfandade e a pobreza justificavam a sua apreensão.

As duras críticas às colônias correcionais ${ }^{15}$ no início do século levam à criação das "escolas de recolhimentos", ou escolas de reformas especiais pelo governo para o atendimento de proteção à infância. Intencionava-se tornar o indivíduo útil e válido para a sociedade através do trabalho. Assim, foram criados os chamados patronatos agrícolas, nos quais a criança devia inserir-se na sociedade produtiva (RIZZINI, Irma 2009). O objetivo era incorporar os "menores tutelados" na vida dos campos. Contudo, essas instituições não duraram muito tempo sob a alegação de não passarem de asilos.

A política de controle social dos anos 1930 traz em seu bojo maior intervenção do Estado, mas a assistência oficial desse período seguiu a tradição das iniciativas caritativas, que se constituíram basicamente em um sistema de atendimento de caráter correcional, reformista e repressivo, materializado através dos institutos, internatos, reformatórios, escolas premunitórias e correcionais.

No Estado Novo, período ditatorial iniciado em 1937 com o Golpe de Estado, o governo federal inaugurou uma política mais nítida de proteção e assistência ao "menor" e a infância, representada pela criação de órgãos federais que se especializaram no atendimento a essas duas categorias agora separadas: o menor (carregada pelo binômio carência/delinqüência) e a criança (as demais crianças que não se inseriam na categoria “menor").

Essas duas categorias assumiram conotações independentes, passando a ser alvo de políticas diversas, em que o "menor" permanece na esfera policial-jurídica, sob controle do Ministério da Justiça, e a criança é exclusividade da esfera médico educacional, cujas ações são coordenadas pelo Ministério da Saúde.

\footnotetext{
${ }^{14}$ Nessas colônias, uma vez internado, o jovem lá permanecia até os 17 anos, cabendo somente ao Juiz de Órfãos sustar a internação.

${ }^{15}$ Uma visita feita em 1912 pelo Ministro de Justiça da época, Ataulpho de Paiva, constatou que esse modelo agredia os novos ideais de assistência onde promiscuidade e ociosidade eram indesejáveis. Debaixo de duras críticas, a colônia foi extinta em 1914, mas há relatos de que ela teria sobrevivido a várias tentativas de extinção, deixando de receber "menores" somente em 1927 com a publicação do Código de Menores. (RIZZINI, IRMA, 2009, p.225-286).
} 
Em 1941, foi criado o Serviço de Assistência ao Menor (SAM), órgão federal responsável pelo controle da assistência, oficial e privada, em escala nacional com o objetivo de desenvolver em todo o país o amparo social aos "menores abandonados e infratores", sendo redefinido em 1944. Porém, no final de 1950 e início de 1960, essa instituição se transformou em foco de crítica e pressão da sociedade, pois ao invés de "ressocializar" os jovens, institucionalizava-os, aplicando medidas repressivas (TÔRRES et al, 1998).

Desvio de verbas, ensino precário, superlotação, incapacidade de recuperação dos internos foram também alguns dos problemas que levaram à extinção do SAM, em 1964, pela Lei n 4513 que também criou a Fundação Nacional de Bem Estar do Menor - FUNABEM, que tinha por missão estabelecer diretrizes que se opunham àquelas criticadas no SAM (RIZZINI e RIZZINI, 2004).

Assim, o primeiro embate desta nova instituição foi enfrentar a "herança que o SAM" deixou, formulando assim, a Política Nacional de Bem-Estar do Menor PNBEM, com gestão centralizada e verticalizada, e tônica de valorização da vida familiar, e "integração do menor na comunidade".

Para cumprir a função de repassar recursos, contou-se com organismos que deveriam se encarregar da aplicação desses recursos, em nível local, o que deu origem às Fundações Estaduais de Bem-Estar do Menor (FEBEMs).

Entretanto, as propostas da FUNABEM não renderam o fruto esperado, pois na prática era mais um instrumento de controle do regime político autoritário exercido pelos governos militares. Além disso, os prejuízos resultantes da marginalização tinham aumentado. Cabe destacar que havia uma grande tendência de internar crianças em idade escolar, tanto que a legislação menorista confirmava e reforçava a concepção da incapacidade das famílias pobres em educar os filhos.

Nesse mesmo período, setores das próprias instituições começavam a questionar o modelo de atendimento, engrossando as fileiras dos que pregavam mudanças. Discussões impulsionaram a elaboração de uma nova legislação, que fosse apoiada na então Convenção Internacional dos Direitos da Criança, aprovada pela Assembléia Geral das Nações Unidas - ONU, em 1989 (BRASIL, 2009).

Constata-se a falência do modelo da FUNABEM e da inviabilidade da concepção de atendimento correcional-repressivo e assistencialista com gestões 
centralizadas e verticais, e também da reprodução estereotipada do menor representado como um feixe de carências.

As produções acadêmicas da época também mostravam a falência do sistema de atendimento e o efeito perverso que o internato produzia nas crianças e adolescentes. Relatórios e Projetos ${ }^{16}$ demonstravam que até 1975, havia predominado um paradigma corretivo, para o qual crianças "carentes ou abandonadas" constituíam a base estrutural de recrutamento da criminalidade urbana.

Combater a pobreza e reduzir as desigualdades sociais era um empreendimento socialmente útil, na medida em que se evitava que o "menor" carente viesse a se tornar abandonado e, este por sua vez, infrator.

Este modelo, no entanto, revelou-se autoritário porque privilegiava a família "bem integrada", ditas "normais" como critério de socialização. Era também vista como perversa porque entendia as obrigações éticas como necessidades estratégicas. E, por fim, dita irrelevante, por se revelar incapaz de sanar a "patologia" identificada sem recorrer à institucionalização do "menor" basicamente em internatos, que, fechavam o círculo vicioso, produzindo novamente, carreiras criminosas (VOGEL, 2009).

Outro problema destacado foi a falta de articulação e integração das instâncias, organismos e programas, voltados para o atendimento da criança e do adolescente, pois não existia de fato uma política, e sim medidas de cunho social. E, assim, os anos 80 do século XX surgem no campo das políticas de atendimento à infância e adolescência como um tempo de grandes transformações.

\subsection{Diretrizes das Políticas públicas para a infância a partir do ECA.}

Assim, em meio ao processo de redemocratização e da organização dos setores da classe trabalhadora, e de um amplo processo de calorosos debates, surgiu o Estatuto da Criança e do Adolescente - ECA - em substituição ao "Código de menores", através da lei 8096, de 1990.

Essa lei estabelece em seu artigo primeiro, a proteção integral à criança e ao adolescente, introduzindo uma nova concepção à legislação referente à infância e adolescência até então em vigor no país. Neste sentido, o ECA caracteriza um

\footnotetext{
${ }^{16}$ Destaca-se aqui o "Projeto Diagnóstico Integrado para Uma Nova Política de Bem Estar", patrocinado pela FUNABEM. (VOGEL, 2009, p.287-321).
} 
importante avanço com a importante mudança terminológica: não mais se utilizando o estigma "menor" e sim "Criança e adolescente".

Com o ECA, a garantia dos direitos fundamentais deveria ser efetivada por meio de um conjunto de ações governamentais e não governamentais da União, dos Estados e dos Municípios, tendo como prioridade as políticas sociais básicas, os programas de assistência social, em caráter supletivo, para aqueles que deles necessitem e serviços especiais de prevenção e atendimento médico e psicossocial às vítimas de negligência, maus tratos, exploração, abuso, crueldade e opressão (BRASIL, 1990, art. 86 e 87).

Nesse sentido, a lei exige que os direitos sociais sejam a expressão social do Estado e que, através dele, seja feita a gestão das políticas sociais.

Esta Concepção pressupõe o desenvolvimento de políticas universais e integradas, estruturadas sob o princípio de uma gestão pública participativa (OLIVA e KAUCHAKJE, 2009). Assim, têm-se procurado sincronizar as políticas públicas à lógica do ECA.

Após a Constituição de 1988, os municípios deixaram de ser unidades meramente administrativas e assumem, ao lado dos Estados, novas atribuições, adquirindo maior autonomia e poder de decisão, tendo a perspectiva no novo ordenamento de se auto-organizar por meio da participação da sociedade civil numa tentativa de enfrentamento à problemática social constatada na infância e na juventude

Nessa época surgiu também a figura dos "educadores de rua" que desenvolviam atividades pedagógicas nas ruas, rompendo com a tradicional postura de trabalhar em local fechado, passando a atuar ao encontro dos jovens. Esses educadores passaram também a ser identificados como símbolo da luta contra a política oficial de atendimento.

Em 1990, já completamente desgastada pelos mesmos sintomas que levaram à extinção do SAM, a FUNABEM, num esforço de revisar sua metodologia, transformouse no CBIA - Centro Brasileiro para a Infância e Adolescência. O ECA surgiu como uma negação dessas duas instâncias, o que acabou por extinguir o CBIA em 1995. 
Sobre as mudanças de concepção que de fato ocorreram com o advento do ECA em relação ao antigo Código de menores, Brancher (2000) ${ }^{17}$ mostra um quadro comparativo que destaca alguns pontos:

\begin{tabular}{|c|c|c|}
\hline ASPECTO & ANTERIOR & ATUAL \\
\hline Doutrinário & Situação Irregular & Proteção Integral \\
\hline Caráter & Filantrópico & Política Pública \\
\hline Fundamento & Assistencialista & Direito Subjetivo \\
\hline $\begin{array}{l}\text { Centralidade } \\
\text { Local }\end{array}$ & Judiciário & Município \\
\hline $\begin{array}{l}\text { Competência } \\
\text { Executória }\end{array}$ & União/Estados & Município \\
\hline Decisório & Centralizador & Participativo \\
\hline Institucional & Estatal & $\begin{array}{c}\text { Co-gestão da Sociedade } \\
\text { Civil }^{18}\end{array}$ \\
\hline Organização & Piramidal Hieráquica & Rede \\
\hline Gestão & Monocrática & Democrática. \\
\hline
\end{tabular}

Conforme o demonstrado no quadro, com o ECA passou-se a demandar uma integração com as várias políticas públicas. Há também uma maior autonomia conferida aos municípios, além do aumento da participação da sociedade na gestão e execução das políticas de atendimento à infância e adolescência.

Quanto ao atendimento em si, sabe-se que as crianças que chegam atualmente às instituições são as órfãs ou em situação de abandono infantil, ou por estarem em situação de pobreza ou ainda por se encontrarem em situação de alto risco, situação em

\footnotetext{
${ }^{17}$ Fonte: MACIEL, Kátia Regina F.L.Andrade. Curso de Direito da Criança e do Adolescente: Aspectos teóricos e práticos, p.15. $4^{\mathrm{a}}$ Edição. Lumen Juris Editora. Rio de Janeiro, 2010.

${ }^{18} \mathrm{~A}$ sociedade civil é um terreno onde se dá uma batalha de diferentes projetos de hegemonia, ou seja, é um terreno de luta de classes, visando mudar as relações de poder da sociedade. Nesse contexto brasileiro, essa expressão representava a esfera da auto-organização e de interesses, e uma crescente socialização da participação política. O termo foi popularizado porque havia uma oposição dura ao Estado ditatorial brasileiro, o que supunha que tudo que vinha do Estado era ruim. Porém, com o passar do tempo essa expressão passou por modificações, passando a ser confundida com o chamado "terceiro setor", como se verá adiante.
} 
que devido a casos de violência, crises familiares ou catástrofes, encontram-se impedidos de retornar a seus locais de moradia (RIZZINI et RIZZINI, 2004).

Sabe-se que, seja qual for a origem dessas crianças que chegam às instituições, todas apresentam traços em comum, devido a muitas mudanças e constantes rompimentos de seus elos efetivos, além de uma grande demanda por atenção e cuidados que poucas vezes é correspondida.

Pela doutrina da proteção integral hoje funcionam Conselhos de Direitos e Conselhos tutelares, Juizados Especiais, Delegacias de Proteção à Criança e ao Adolescente (DPCAs) quando vítimas de crimes, Delegacias Especializadas de Crianças e Adolescentes, quando flagrados em algum tipo de delito, dentre outros.

Várias mudanças na lei também foram instituídas em relação à questão da internação, dependendo da natureza da medida aplicada, como por exemplo, o abrigo, que é aplicado como uma medida de caráter provisório e excepcional de proteção para crianças em situações consideradas de risco pessoal e social; e a internação como medida socioeducativa para adolescentes em privação de liberdade.

Houve nesse contexto, propostas para criação de alternativas institucionais em meio aberto visando integrar a criança em seu meio social, especialmente no que concerne à aplicação das medidas socioeducativas ao adolescente autor de ato infracional, na qual talvez o mais inovador seja a participação da comunidade no processo educativo.

\section{CAPÍTULO 2: POLÍTICAS SOCIAIS PÚBLICAS NO CONTEXTO NEOLIBERAL}

Ao longo da história brasileira, o Estatuto da Criança e do adolescente (ECA), sem dúvida, constituiu-se na lei federal mais debatida pelo conjunto da sociedade brasileira, em um processo inédito de organização e articulação popular. Sua filosofia leva à compreensão acerca da importância das políticas sociais, fundamentais para o estabelecimento das condições necessárias para assegurar a proteção integral da qual, crianças e adolescentes, são destinatárias.

Contudo, embora a Constituição Federal e o ECA representem um avanço importante na história da atenção à infância e à juventude, existem alguns impasses e dificuldades experienciadas na tentativa de implementar a Doutrina da Proteção 
Integral, pois ainda hoje a herança de descaso e o enfoque punitivo estão presentes no trato ao adolescente.

Tejadas (2008) aponta a existência, nos últimos anos, de enxugamento nos gastos em políticas sociais, no qual o Estado, nos diferentes níveis, vem utilizando as "parcerias" com a sociedade civil ${ }^{19}$. Dessa forma, organizações não-governamentais passam a ser prestadoras de serviços voltadas para crianças e adolescentes. Sobre essas políticas, em geral, o poder público possui pequeno ou quase nenhum controle, de modo que, muitas vezes, reproduzem práticas excludentes. $\mathrm{O}$ entendimento desse processo será esclarecido no próximo item.

\subsection{A contra-reforma do Estado neoliberal e o terceiro setor}

No período pós-1970 com a chegada da crise do modelo Keyesianista/Fordista, ${ }^{20}$ ganham terreno as idéias neoliberais, reprodutoras da ideologia de que essa crise deu-se devido ao poder excessivo dos sindicatos, e de maneira mais geral, do movimento operário, que havia corroído as bases da acumulação capitalista com suas pressões reivindicatórias para que o Estado aumentasse cada vez mais os gastos sociais.

A solução, segundo Anderson (2008, p.11) era muito clara: "Manter um Estado forte, sim, em sua capacidade de romper o poder dos sindicatos e no controle do

\footnotetext{
${ }^{19}$ A Sociedade Civil, entendida no Brasil atualmente, incorpora a visão do pensamento neoliberal que se aproveitou do contexto ditatorial para dizer que tudo o que vem do Estado é "ruim", e tudo que vem da sociedade civil é "bom". Portanto, inseriu-se como uma forma de se privatizar o que é estatal. Essa sociedade civil é freqüentemente confundida com terceiro setor e com a sociedade de mercado. Porém, nem mesmo nesse conceito a Sociedade civil é homogênea. Duarte $(2008$, p.11) acrescenta que "o que ocorre no presente momento é uma deturpação da categoria sociedade civil, desconsiderando, principalmente, aspectos econômicos e políticos no contexto da sociedade capitalista, isentando-a do conflito e da contradição a ela inerentes; como se constituísse um espaço homogêneo de interesses, o que permite atender à necessidade contemporânea do capital de redução do Estado no tratamento da questão social". A autora (2008, p.11) explica ainda que a idéia de "sociedade civil homogênea" garante um duplo movimento funcional ao capital: econômico, com redirecionamento dos recursos do Estado para o financiamento dos projetos de interesse da burguesia; e ideológico, pois obscurece a luta de classes e, assim, fragiliza a resistência da classe trabalhadora.

${ }^{20}$ Behring e Boschetti (2007, p.120) defendem que a crise do modelo keynesianista/Fordista foi propiciada por encontro de crises clássicas de superprodução, contenção brusca dos rendimentos tecnológicos, crise do sistema imperialista, crise social e política nos países imperialistas, com ascensão das lutas, função do início das políticas de austeridade, e crise de credibilidade do capitalismo, enquanto sistema capaz de garantir o pleno emprego, o nível de vida e as liberdades democráticas. As autoras defendem ainda que a acumulação capitalista não depende exclusivamente de assegurar condições de reprodução, mas também de se orientar para esferas portadoras de altos ganhos de produtividade. Anderson (2008) defende ainda que houve uma combinação de baixas taxas de crescimento com altas taxas de inflação.
} 
dinheiro, mas parco em todos os gastos sociais e nas intervenções econômicas". A estabilidade monetária deveria ser a meta suprema de qualquer governo.

Para isso, seria necessária uma disciplina orçamentária, com a contenção dos gastos com bem-estar, e a restauração da taxa "natural" de desemprego, associada a reformas fiscais, com redução de impostos para os altos rendimentos. Assim, uma "nova e saudável" desigualdade iria voltar a dinamizar as economias avançadas, e o crescimento retomaria quando a estabilidade monetária e os incentivos essenciais houvessem sido restituídos.

Para os neoliberais, o Estado não deveria intervir na regulação do comércio, nem na regulação dos mercados financeiros. Acreditavam ainda, que a proteção social garantida pelo Estado é perniciosa para o desenvolvimento econômico, pois aumenta o consumo e diminui a poupança da população.

Behring e Boschetti (2007) afirmam que a hegemonia neoliberal na década de 1980 nos países capitalistas não foi capaz de resolver a crise do capitalismo nem alterou os índices de recessão e baixo crescimento econômico. Contudo, houve redução dos postos de trabalho e a desaceleração na criação de novos empregos, o que agudizou as desigualdades sociais, através de uma reestruturação produtiva ${ }^{21}$, que junto a mudanças na organização do trabalho, provocaram a precarização das relações trabalhistas.

A hegemonia neoliberal provocou, assim, importantes reconfigurações nas políticas sociais, na qual Behring (2008) destaca a desregulamentação dos direitos, corte dos gastos sociais e o "mérito individual" como ideologia para se garantir conquistas e melhorias fundadas no próprio bem-estar.

Essas mudanças aparecem nos Estados sob o título de "Reformas" que, na verdade, têm sido um sistemático desmonte da estrutura estatal com o objetivo de fazer retroceder, sobretudo, os direitos sociais. A esse fenômeno, Behring (2008) intitula Contra- Reforma do Estado ${ }^{22}$.

\footnotetext{
${ }^{21}$ Segundo Montaño (2008), a reestruturação produtiva combinou uma redução das taxas de inflação com políticas monetárias e fiscais austeras e ao crescimento do desemprego, o que reduziu o percentual de ajustes de salários, combinado à diminuição de preços de matérias-primas no mercado internacional, sobretudo no setor de manufatura.

${ }^{22}$ Historicamente, o termo "Reforma" associava-se às conquistas obtidas no Welfare State, ou seja, às reformas ocorridas no interior do capitalismo, sob a pressão dos trabalhadores. Em contraposição, a "Reforma" proposta pelo projeto neoliberal configura-se numa reação burguesa, conservadora e monetarista, de natureza claramente regressiva, dentro da qual se situa a contra-reforma do Estado.
} 
Essa perspectiva contra-reformista muitas vezes faz-se sob um pretexto de geração de empregos, mas que na verdade, segmentam trabalhadores, fortalecendo situações de precariedade que é atravessado por um processo de flexibilização baseado numa desconstrução da relação salarial. Dentro dessa lógica, há um processo de mundialização dos mercados intensificados pela revolução tecnológica e por um afastamento dos obstáculos à circulação do fluxo de mercadorias e dinheiro, pela via da contra-reforma do Estado.

Behring (2008) posiciona-se, nesse aspecto, que os Estados nacionais restringem-se a cobrir o custo de algumas infra-estruturas, aplicação de incentivos fiscais, garantia de escoamentos suficientes e institucionalização dos processos de liberalização, desregulamentação e flexibilização em nome da competitividade.

No Brasil, a Contra-Reforma do Estado deu-se, sobretudo, a partir dos anos 1990. Nesse aspecto, Behring (2008, p.54) afirma que

Generaliza-se uma política de defesa do capital de empréstimo, com taxas de juros positivas e inflação zero, combinada a uma política fiscal sobre o capital, transferindo-a para os rendimentos do trabalho: o receituário da contra-reforma brasileira nos anos 1990

No Brasil essa "Contra-Reforma" do Estado conduziu também a mudanças estruturais regressivas, o que ocasionou desmonte dos direitos conquistados, principalmente aqueles previstos na Constituição Federal de 1988. As tendências de desresponsabilização e desfinanciamento da proteção social pelo Estado configuraram assim a existência de um "Estado mínimo" para os trabalhadores e um "Estado máximo para o capital". Essa "reforma" é compatível e funcional à atual política macroeconômica de orientação neoliberal.

Nessa Contra-Reforma Brasileira houve um pacto de modernização para realizar liberalizações comerciais, privatizações, estabilização monetária e principalmente, o enxugamento do Estado.

Paralelo a estes "avanços" preconizados pelo projeto neoliberal, existia a promessa de estimular o bem-estar social no país. No entanto, o impacto em termos de aumentar a capacidade de implantação eficiente de políticas públicas foi mínimo. Houve, na verdade, uma forte tendência de desresponsabilização do Estado em relação 
às políticas sociais, além de se reduzir na prática o padrão de Seguridade Social conquistado na Constituição Federal de 1988. A reforma neoliberal possibilitou, sobretudo, o desmonte dessas políticas, particularmente por meio da privatização, focalização e descentralização.

Sob este novo reordenamento, o Estado perde seu protagonismo e adquire um papel coordenador e suplementar diante das políticas sociais - em detrimento do seu papel de provedor dos bens sociais - tendo em vista que parcela significativa das políticas sociais passa a ser executada por organizações públicas não-estatais, que compõem o chamado "terceiro setor" ${ }^{23}$. Dessa forma, as políticas sociais perdem, paulatinamente, seu estatuto de direito social conquistado na Constituição Federal de 1988 e nas Leis específicas e passam a assumir, cada vez mais, características conservadoras como a "refilantropização", focalização, mercantilização e seletividade. Entre as conseqüências trazidas pela contra-reforma, destacam-se: o aumento do desemprego, o corte nos gastos sociais, a flexibilização dos direitos e a privatização dos serviços.

Mais um aspecto relevante da Reforma foi o anúncio do discurso de combate à crise fiscal e o equilíbrio das contas públicas nacionais. Houve a entrega de parcelas significativas do patrimônio público ao capital estrangeiro, o que acarretou o desmonte de partes do parque industrial nacional, uma enorme remessa de dinheiro para o exterior, desemprego e desequilíbrio da balança comercial.

Outro elemento identificado no processo de contra-reforma, denominado de publicização, que segundo Dantas et al (2010) é entendido como a denominação ideológica dada à transferência de responsabilidade das questões públicas para o

\footnotetext{
${ }^{23}$ Entende-se por "terceiro setor" as organizações que abrigam entidades privadas com finalidade pública. Sua atuação realiza-se por meio da produção de bens e prestação de serviços, para o enfrentamento da questão social inserido no atual processo de reestruturação do capital. Montaño (2008) esclarece que esse termo é funcional ao processo de reestruturação do capital, uma vez que minimiza a intervenção do Estado no enfrentamento da questão social e cria uma idéia de falso consenso e aliança entre as classes sociais, o que fragiliza a resistência dos trabalhadores na conquista e garantia de direitos sociais. $\mathrm{O}$ motivo de essa expressão vir utilizada entre aspas neste trabalho é que esta pesquisadora não acredita na existência real desta expressão, uma vez que fragmenta a realidade e retira a funcionalidade desta diante da conjuntura atual de reestruturação geral do capital.

Cf: MONTAÑO, Carlos. Terceiro Setor e Questão Social. Crítica ao padrão emergente de intervenção Social. $5^{\text {a }}$ Ed. Cortez Editora. São Paulo, 2008.
} 
chamado "terceiro setor" (conjunto de entidades públicas "não-estatais", mas regido pelo direito civil privado) e o repasse dos recursos públicos para o âmbito privado. Parte-se da premissa de uma privatização de serviços sociais e de alguns dos recursos públicos, pautando-se numa perspectiva desuniversalizante, contributivista e desconstitutiva de direitos sociais.

Existe um amplo debate acerca do termo Terceiro Setor. Estudiosos afirmam que este termo surgiu a partir de um recorte liberal da realidade social em esferas, ou seja, uma setorialização da sociedade: o Estado (primeiro setor), o Mercado (segundo setor) e a Sociedade Civil (terceiro setor), sendo, portanto, vaga e imprecisa a sua conceituação. A composição do "terceiro setor" causa polêmica, pois não existem regras específicas para enquadrá-los. Alguns consideram que ele é composto pelas entidades privadas, Organizações não-governamentais (ONGs), sem fins lucrativos, autogovernadas e associações voluntárias. Porém a definição mais corriqueira refere-se a ações da sociedade civil.

Nesse processo de Contra-Reforma do Estado há uma corriqueira confusão sobre o Terceiro Setor e Sociedade Civil. Segundo Montaño (2008), as organizações que se incluem no chamado "terceiro setor" referem-se apenas a instâncias de ajuda ao próximo e auto-ajuda (parcerias). Já o conjunto de organizações da sociedade civil abarca também as atividades classistas e de luta político-econômica e até revolucionárias. O problema é que na atualidade utiliza-se o termo Sociedade Civil para o lado de uma suposta negociação, acordo, parceria entre as classes, quando o caminho histórico da sociedade civil leva a uma luta pela superação da ordem do capital, no trânsito para uma sociedade sem oprimidos nem explorados. Em Gramsci (COUTINHO, 1999), a sociedade civil tem mais um sentido de conjunto de organismos não estatais através das quais as classes dominantes exercem a direção pela via do consenso.

No entanto, esta definição de Sociedade civil no processo de "contra-reforma" abre brechas para vários tipos de entidades ditas "sem fins lucrativos" que não se caracterizam como tais, objetivando claramente a obtenção de lucro. 
Montaño (2008) defende a idéia de que, embora se apresente como uma "alternativa" aos outros dois setores (Estado e Mercado), o "terceiro setor" está inserido e integrado de forma funcional ao sistema capitalista. Dessa forma, é ingênuo pensar que as atividades filantrópicas das empresas (chamadas de Responsabilidade Social Empresarial $^{24}$ ou iniciativa privada), não visam, mesmo que de forma indireta e encoberta, a fins lucrativos. Nessa via há um movimento de privatização das respostas às expressões da questão social que se caracteriza não somente na refilantropização do social, mas também na mercantilização do atendimento das necessidades sociais através da prestação de vários serviços.

Existem certamente, ações do "terceiro setor" voltadas à mobilização da sociedade em vários aspectos, mas a questão é que estas, em geral, são pontuais e emergenciais, não resolvendo a médio e longo prazo a situação da população que se utilizam dos seus serviços, consolidando, apenas uma relação de dependência da população por estas ações. Além disso, anulam através do Estado democrático a possibilidade de considerá-lo um espaço significativo de lutas de classes e sociais, e como mantenedor da ordem e ampliação da acumulação capitalista, porém também como garantidor de certo nível de "conquistas" sociais ali desenvolvidas (MONTAÑO, 2008).

Estes mecanismos de transferência de responsabilidade e de recursos do Estado para o setor privado fortalecem o projeto neoliberal de Estado mínimo para o social, deixando a cargo da sociedade, via solidariedade e filantropia, o atendimento das demandas sociais das camadas empobrecidas. As instituições do "terceiro setor" executam e fazem a gestão de alguns projetos e programas sociais, no entanto, não são obrigados a garantir os mínimos sociais que o Estado possui. Assim, torna-se fácil atender ao público de forma seletiva, focalizada, de acordo com os interesses de cada

\footnotetext{
${ }^{24}$ Conforme Behring e Menezes (2007, apud Dantas et al, 2010), a chamada "Responsabilidade Social das Empresas" (RSE) é um tema complexo, que envolve desde a condução da Política Social no país, particularmente no campo da Assistência Social, tendo como pano de fundo o avanço do neoliberalismo e a minimização dos serviços sociais públicos, visando o enxugamento de gastos do Estado e a privatização/terceirização desses serviços, além das estratégias do capitalismo em busca da acumulação. A RSE faz parte de uma estratégia de acumulação capitalista, em que os grandes empresários, ao utilizarem as famosas "parcerias" como mecanismo de marketing acaba conquistando espaço na mídia, simpatia e confiança dos consumidores, vultosas isenções fiscais e, acima de tudo, lucros extraordinários.
} 
empresa, instituição ou entidade isoladamente, comprometendo a qualidade dos serviços.

Além disso, não existe um controle sobre o processo de escolha ou triagem dos beneficiários. Os critérios são estipulados pelas empresas ou por suas fundações, que escolhem o público alvo de acordo com seus interesses, geralmente em curto prazo, o que leva, muitas vezes, a execução de ações superficiais, paliativas, com grande impacto e visibilidade na mídia, sem sustentação em longo prazo, mas que garantem lucros imediatos.

Quanto ao financiamento das políticas sociais no final da década de 1980 e início da década de 1990, o Brasil passou também a adotar políticas de contenção de gasto público, com cortes seguidos no gasto social, atendendo as orientações de organismos internacionais como o Banco Mundial (BM) e o Fundo Monetário Internacional (FMI), cumprindo, evidentemente, os preceitos neoliberais.

A justificativa que vem sendo utilizada para a redução dos gastos sociais é a escassez de recursos públicos, propondo, assim, para enfrentamento da crise, um conjunto de medidas, como a Reforma do Estado, desvinculações orçamentárias recentralização dos recursos na esfera federal e a focalização e seletividade das políticas sociais.

Isso vai incidir diretamente na execução das políticas atuais de atenção à criança e adolescentes, o que ocasionará não apenas reduções no investimento às políticas e programas voltados a essa parcela populacional, mas também focalizações e desmontes às redes de proteções sociais, como, no caso do nosso objeto de estudo, a Liberdade Assistida no Distrito Federal, através do SINASE.

\section{Capítulo 3- O ADOLESCENTE AUTOR DE ATO INFRACIONAL NO CUMPRIMENTO DAS MEDIDAS SOCIOEDUCATIVAS}

A História Social e das Políticas Públicas destinadas às crianças e adolescentes no Brasil mostram que, muito embora o ECA (1990) tenha servido para dar fim à era do Código de Menores, ainda hoje, a infância e a adolescência representam a parcela mais exposta às violações de direitos pela família, pelo Estado e pela Sociedade. 
Inseridos no contexto de criminalização social encontram-se os adolescentes que cometem ato infracional. Isso acontece porque se sabe que é longa a tradição repressiva no tocante ao trato da criança e do adolescente. Persistem ainda práticas de caráter repressivo na aplicação das medidas socioeducativas, retrocedendo-se ao velho paradigma, em total descumprimento das garantias e prerrogativas legais advindas com o Estatuto de 1990.

O adolescente em conflito com a lei se encontra muitas vezes sob exposição de violações dos seus direitos, mas por terem cometido um ato infracional, são desqualificados enquanto adolescentes. A segurança é entendida como a fórmula mágica de "proteger a sociedade" da violência produzida por "desajustados sociais" que precisam ser afastados do convívio social, recuperados e reincluídos. É difícil para o senso comum juntar a idéia de segurança e cidadania. Segundo Volpi (1997) reconhecer no agressor um cidadão parece ser um exercício difícil e, para alguns, inapropriado, pois seria como se este não fosse um sujeito, vítima e marcado pelas determinações da conjuntura sócio-histórica.

Assim, crescem os preconceitos e alastram-se explicações simplistas, ficando a sociedade exposta a um amontoado de informações desencontradas e desconexas usadas para justificar o que, no fundo, não passa de uma estratégia de criminalização da pobreza; ou seja, uma tentativa de a todo custo encontrar um "culpado" para uma questão que, na realidade, é consequiência de uma série de fatores-causa da criminalidade como um todo.

Esses fatores incluem as questões sócio-econômicas porque estamos inseridos em uma sociedade capitalista que dita uma grande diferenciação entre as classes sociais, e também faz com que haja uma grande massa de miseráveis. Essa parcela populacional se vê privada de tudo, inclusive da dignidade de criaturas humanas.

Na realidade, muitas crianças não têm infância em razão de sua miséria, o que faz com que a adolescência envolvida com a criminalidade se construa a partir, não somente, de uma negação de direitos, tais como escola, saúde, família, dentre outros, mas também de uma não efetivação desses direitos como um todo. Dessa forma, o respeito aos seus direitos e garantias deve ter por base o fato de serem humanos, num processo singular de desenvolvimento, que os conduz a necessidades específicas. 
E essa garantia do adolescente ser considerado um ser humano, em essência, é destacada em vários documentos na área da infância e da juventude, como por exemplo, a Convenção Internacional dos Direitos da Criança, ratificada pelo governo brasileiro, que instituiu a criança dentro do universo da Doutrina da proteção integral, na qual

Afirma o valor intrínseco da criança como ser humano; a necessidade de respeito à sua condição de pessoa em desenvolvimento; o valor prospectivo da infância e da juventude, como portadora da continuidade do seu povo e da espécie e o reconhecimento da sua vulnerabilidade, o que torna as crianças e os adolescentes merecedores de proteção integral por parte da família, da sociedade e do Estado, o qual deverá atuar através de políticas específicas para promoção e defesa de seus direitos (COSTA, 1992 apud VERONESE, RODRIGUES, 2001).

A Constituição Federal e o Estatuto da Criança e do Adolescente, em consonância com a Doutrina das Nações Unidas de Proteção Integral dos Direitos da Criança ${ }^{25}$ instalaram um "sistema de proteção geral de direitos" denominado Sistema de Garantia de Direitos (SGD), cujo intuito é a efetiva implementação da Doutrina da Proteção Integral. No interior do SGD existem diversos subsistemas que tratam de situações peculiares e outros que regem as políticas sociais básicas, de assistência social, proteção especial e de justiça, voltados ao atendimento de crianças e adolescentes (BRASIL, 2006). Os adolescentes autores de ato infracional não devem ser excluídos de tal proteção.

O Estatuto da criança e do adolescente surgiu no cenário jurídico com o objetivo de situar a criança, pessoa até doze anos de idade incompletos, e o adolescente, entre doze e dezoito anos de idade, enquanto sujeitos de direitos, optando por afastar-se do sistema punitivo ${ }^{26}$.

\footnotetext{
${ }^{25}$ A Doutrina das Nações Unidas de Proteção Integral dos Direitos da Criança baseiam-se em algumas normativas internacionais que compreendem a Doutrina da Proteção Integral dos Direitos da Criança. Dentre elas, destacam-se a Convenção das Nações Unidas sobre os Direitos da Criança (1989/1990); Regras Mínimas das Nações Unidas Para a Administração da Justiça da Infância e da Juventude (Regras de Beijing/1984); Diretrizes das nações Unidas para a Prevenção da Delinqüência Juvenil (Diretrizes de Riad/1990); Regras mínimas das Nações Unidas para a elaboração de medidas Não Privativas de Liberdade (Regras de Tóquio/1990) e Regras Mínimas das Nações Unidas para a Proteção dos Jovens Privados de Liberdade (1991).

${ }^{26} \mathrm{O}$ artigo 105 do Estatuto determina que ao ato infracional praticado por uma criança são cabíveis as medidas do artigo 101, que são chamadas de medidas de proteção; Já o adolescente em conflito com a lei penal, pode tanto estar sujeito às medidas de proteção, como às medidas socioeducativas, sendo-lhe aplicáveis conforme a gravidade e o potencial de agressividade do ato.
} 
Para a elaboração de parâmetros e diretrizes para a execução das medidas socioeducativas $^{27}$ dos adolescentes em conflito com a lei, o CONANDA - Conselho Nacional dos Direitos da Criança e do Adolescente - criou um documento em maio de 2006, chamado Sistema Nacional de Atendimento Socioeducativo (SINASE). O SINASE, posteriormente instituído no projeto de Lei 1627/2007 aprovado pela Câmara dos Deputados, define-se no "conjunto ordenado de princípios, regras e critérios, de caráter jurídico, político, pedagógico, financeiro e administrativo, que envolve desde o processo de apuração de ato infracional até a execução de medida socioeducativa" (BRASIL, 2006). Dispõe também de todas as políticas, planos, e programas específicos de atenção a esse público.

O SINASE constitui ainda um subsistema específico do SGD relacionado aos adolescentes em conflito com a lei, o qual se comunica e sofre interferência das demais áreas de atuação, tais como saúde, Educação, Assistência Social, Justiça e Segurança Pública (BRASIL, 2006).

Esse sistema nacional inclui os sistemas estaduais, distrital e municipal, bem como todas as políticas, planos, e programas específicos de atenção a esse público (BRASIL, 2006). Assim, o SINASE constitui-se como uma política pública destinada à inclusão do adolescente em conflito com a lei que se correlaciona e demanda iniciativa dos diferentes campos das políticas públicas e sociais. (ibidem).

Um dos princípios pelo qual esse atendimento ao adolescente deve reger-se é a municipalização do atendimento (art.88 I ECA) como meio de sua eficácia. O projeto que institui o SINASE disciplina ainda de que forma os governos federal, estadual e municipal devem aplicar as medidas socioeducativas e dispõe sobre o cofinanciamento. Pela proposta, caberá aos municípios a aplicação das medidas em meio aberto (Liberdade Assistida e Prestação de Serviços à Comunidade); os estados ficarão responsáveis pela internação provisória e as medidas socioeducativas de internação e de semiliberdade; a União ficará encarregada das diretrizes gerais das políticas destinadas ao adolescente em conflito com a lei. (ibidem)

\footnotetext{
${ }^{27} \mathrm{O}$ termo Sistema Socioeducativo refere - se ao conjunto de todas as medidas privativas de liberdade (internação e semi - liberdade), as não privativas de liberdade (liberdade assistida e prestação de serviço à comunidade) e a internação provisória.
} 
O SINASE visa trazer avanços não só na discussão sobre o tema, mas, principalmente, na efetivação de uma política que contemple os direitos humanos, buscando transformar a problemática realidade atual em oportunidade de mudança, além de prover mecanismo e princípios regulatórios para o cumprimento das medidas socioeducativas.

\subsection{Medidas Socioeducativas aplicáveis ao adolescente autor de ato infracional}

As Medidas Socioeducativas destinam-se aos adolescentes que tenham cometido algum ato infracional, que é caracterizado por uma conduta descrita como crime ou contravenção penal, quando praticado por um adolescente.

Essas medidas comportam aspectos de natureza coercitiva, uma vez que são punitivas aos infratores, e aspectos educativos no sentido da proteção integral e oportunização como garantias ao adolescente de superação de sua condição de exclusão, bem como de acesso à formação de valores positivos de participação da vida social, prevendo o envolvimento familiar e comunitário.

O artigo 172 do ECA diz que se o adolescente é apreendido em flagrante, deve imediatamente ser encaminhado à autoridade policial competente. Se for apreendido por ordem judicial, deve ser encaminhado ao juiz. Em qualquer hipótese, sua família, responsável ou pessoa por ele indicada, deve ser também informada, no mesmo ato. Isso é uma grande conquista do Estatuto, já que na antiga categoria "menor", o Estado desautorizava as famílias pobres em seu papel parental. Os sistemas assistenciais daquela época justificavam a institucionalização de criança, acusando os pais de serem incapazes de cuidar dos filhos.

Decorre do reconhecimento do ECA de que o adolescente até os 18 anos é inimputável, pois mesmo quando seu ato é tipificado no Código Penal, ou na Lei de contravenções penais, não se caracteriza como tal. Essa idéia baseia-se no fato de que o adolescente não tem o seu discernimento completo, uma vez que não lhe atribui direitos e deveres próprios dos adultos. Ou seja, não é penalizado nos termos da lei aplicável aos adultos, mas inserido em medidas socioeducativas, com a finalidade de sua inserção social, por ser considerado "pessoa em desenvolvimento." 
Segundo Volpi (1997), as medidas socioeducativas são aplicadas e operadas de acordo com as características da infração, circunstâncias sócio-familiares e disponibilidade de programas e serviços em nível municipal, regional e estadual. Deve também utilizar-se do princípio da incompletude institucional, caracterizado pela utilização do máximo possível de serviços, tais como saúde, educação, defesa jurídica, dentre outros, responsabilizando as políticas setoriais no atendimento aos adolescentes.

As medidas socioeducativas são seis e, no quadro abaixo, serão traçadas sua conceituação, bem como os responsáveis por sua execução, lembrando que todas essas medidas são normatizadas pela União através do SINASE:

\begin{tabular}{|c|c|c|c|}
\hline $\begin{array}{c}\text { MEDIDA } \\
\text { SOCIOEDUCATIVA }\end{array}$ & $\begin{array}{c}\text { MEIO DE } \\
\text { EXECUÇÃO } \\
\text { DA MEDIDA }\end{array}$ & $\begin{array}{c}\text { CARACTERÍSTICAS } \\
\text { DA MEDIDA }\end{array}$ & $\begin{array}{c}\text { RESPONSÁVEL } \\
\text { PELA EXECUÇÃO } \\
\text { DA MEDIDA }\end{array}$ \\
\hline Advertência & Meio Aberto & $\begin{array}{l}\text { Admoestação Verbal, } \\
\text { reduzida a termo e } \\
\text { assinada }\end{array}$ & $\begin{array}{l}\text { Autoridade Judiciária } \\
\text { competente dos } \\
\text { Estados. }\end{array}$ \\
\hline $\begin{array}{ll}\text { Obrigação } & \text { de } \\
\text { reparar o dano } & \end{array}$ & Meio Aberto & $\begin{array}{l}\text { O jovem deverá } \\
\text { restituir, ressarcir, ou } \\
\text { compensar o dano com } \\
\text { reflexos patrimoniais. }\end{array}$ & $\begin{array}{l}\text { Autoridade } \text { Judiciária } \\
\text { competente } \\
\text { Estados. }\end{array}$ \\
\hline $\begin{array}{lr}\text { Prestação } & \text { de } \\
\text { Serviços à } & \text { à } \\
\text { Comunidade- (PSC) }\end{array}$ & Meio Aberto & $\begin{array}{l}\text { Realização de tarefas } \\
\text { gratuitas de interesse } \\
\text { geral por no máximo } \\
\text { seis meses. }\end{array}$ & Municípios \\
\hline $\begin{array}{l}\text { Liberdade Assistida } \\
\text { (LA) }\end{array}$ & Meio Aberto & $\begin{array}{l}\text { Acompanhamento, } \\
\text { auxílio e orientação do } \\
\text { adolescente por um } \\
\text { período mínimo de seis } \\
\text { meses. }\end{array}$ & Municípios \\
\hline
\end{tabular}




\begin{tabular}{|l|l|l|l|}
\hline Semiliberdade & Meio Fechado & $\begin{array}{l}\text { Adolescente recolhe-se } \\
\text { à noite } \text { em um }\end{array}$ & Municípios \\
& & $\begin{array}{l}\text { estabelecimento, mas } \\
\text { durante o dia realiza } \\
\text { atividades externas. }\end{array}$ & \\
\hline Internação & Meio Fechado & $\begin{array}{l}\text { Privação de liberdade } \\
\text { que não pode exceder } \\
\text { três anos, devendo ser }\end{array}$ & Autoridade Executiva \\
dostados (governos \\
revista a cada seis \\
meses.
\end{tabular}

QUADRO 02 - MEDIDAS SOCIOEDUCATIVAS

Fonte: Pesquisa Bibliográfica do trabalho Adolescentes em conflito com a lei: A efetivação da Liberdade Assistida no Distrito Federal.Brasília, 2010.

Conforme pode ser observado no quadro acima, as medidas socioeducativas são divididas entre as que podem ser executadas em meio: a) aberto, como Advertência, Obrigação de Reparar o dano, Prestação de Serviços à comunidade e Liberdade Assistida (LA); e b) em meio fechado, como a Semi-Liberdade e a internação.

No Distrito Federal, o Juiz da Infância e da Juventude- VIJ/DF é o profissional competente para proferir sentenças socioeducativas, após análise da capacidade do adolescente cumprir a medida, das circunstâncias do fato e da gravidade da infração.

Cabe à SEMSE - Seção de Medidas Socioeducativas da $1^{\text {a }}$ Vara da Infância e da Juventude - VIJ/DF acompanhar a Obrigação de Reparar o dano e ao juiz da VIJ/DF aplicar a medida de advertência; as demais medidas são executadas pela Secretaria de Justiça Direitos Humanos e Cidadania do Distrito Federal- SEJUS/DF.

A SEJUS/DF é um órgão ligado ao Poder Executivo do Distrito Federal que tem por premissa "promover o pleno exercício da cidadania e da defesa dos direitos inalienáveis da pessoa humana, mediante ação integrada entre o Governo do Distrito Federal - GDF e a sociedade do Distrito Federal" ${ }^{28}$. Seu objetivo é

Definir diretrizes para a política governamental, bem como a coordenação de sua execução, nas áreas penitenciária, da proteção, da

\footnotetext{
${ }^{28}$ Secretaria de Estado de Justiça, Direitos Humanos e Cidadania. Apresentação geral. Disponível em $\langle$ http://www.sejus.df.gov.br $>$. Último acesso em 09/07/2010.
} 
defesa, da educação e orientação ao consumidor, da defesa dos direitos da cidadania e da pessoa portadora de deficiência, e da assistência jurídica gratuita aos necessitados ${ }^{29}$

Contudo, a SEMSE - Seção de Medidas Socioeducativas da $1^{\mathrm{a}}$ Vara da Infância e da Juventude - VIJ/DF embora não tenha o papel da execução das medidas socioeducativas, ela busca juntamente com a SEJUS/DF estruturar uma rede de atendimento para que os adolescentes cumpram as sentenças determinadas pelo Juiz.

\subsection{O adolescente autor de ato infracional no Distrito Feder}

Em Abril de 2002 foi publicada uma pesquisa pela $1^{\text {a }}$ Vara da Infância e Juventude - VIJ/DF (SILVA, 2000) caracterizando o perfil dos adolescentes no Distrito Federal em cumprimento de medidas socioeducativas em meio aberto entre os anos 1999-2000. Fizemos também uma análise documental nas estatísticas mensais da VIJ/DF, disponíveis para consulta no próprio órgão entre os anos 2007 a 2009, a fim de apurar o perfil do adolescente autor de ato infracional do $\mathrm{DF}^{30}$.

As características dos adolescentes no Distrito Federal, em cumprimento de medida socioeducativa, assemelham-se ao perfil dos adolescentes em conflito com a lei no Brasil. Segundo publicações oficializadas na resolução do SINASE (BRASIL, 2006), $15 \%$ da população brasileira é composta por adolescentes. Destes, $0,2 \%$ (zero vírgula dois por cento) do total de adolescentes na idade de 12 a 18 anos existentes no Brasil estão inseridos no sistema socioeducativo por terem cometido algum ato infracional. $\mathrm{O}$ quadro abaixo mostra um panorama do perfil desses adolescentes no cenário do Distrito Federal que cumprem as medidas em meio aberto, segundo o que foi constatado na pesquisa bibliográfica e análise documental na $1^{\mathrm{a}} \mathrm{VIJ} / \mathrm{DF}$ :

\footnotetext{
${ }^{29}$ ibidem

${ }^{30}$ Cabe ressaltar que as estatísticas da VIJ/DF têm por base os processos de apuração dos referidos adolescentes.
} 


\begin{tabular}{|c|c|c|}
\hline VARIÁVEIS ANALISADAS & $\begin{array}{l}\text { CARACTERÍSTICAS } \\
\text { PREDOMINANTES* }\end{array}$ & $\begin{array}{c}\text { VARIAÇÃO DO } \\
\text { PERCENTUAL } \\
\% \\
\%\end{array}$ \\
\hline SEXO & MASCULINO & 90 a $93 \%$ \\
\hline $\begin{array}{ll}\text { FAIXA } & \text { ETÁRIA } \\
\text { PREDOMINANTE } & \end{array}$ & 16-17 anos & $76 \%$ \\
\hline \multirow{3}{*}{$\begin{array}{l}\text { ATIVIDADES } \\
\text { DESEMPENHADAS }\end{array}$} & - Estudam & $44 \%$ a $52 \%$ \\
\hline & - Trabalham & $26 \%$ \\
\hline & - Nunca estudaram & $0,1 \%$ a $0,2 \%$ \\
\hline \multirow{2}{*}{$\begin{array}{lll}\text { COM QUEM } & \text { VIVIAM } & \text { NA } \\
\text { PRÁTICA } & \text { DO } & \text { ATO } \\
\text { INFRACIONAL } & & \end{array}$} & - Com a mãe & $43 \%$ a $51 \%$ \\
\hline & - Com o Pai e a Mãe & $42 \%$ a $21 \%$ \\
\hline $\begin{array}{ll}\text { ATO } & \text { INFRACIONAL } \\
\text { PRATICADO } & \text { COM MAIOR } \\
\text { FREQUÊNICA } & \end{array}$ & - Roubo & $18 \%$ a $29 \%$ \\
\hline \multirow[t]{2}{*}{ RENDA } & - Menos de um salário mínimo & $33 \%$ \\
\hline & - Entre 1 e 4 salários mínimos & $44 \%$ a $55 \%$ \\
\hline \multirow[t]{4}{*}{ ESCOLARIDADE } & - Não freqüentavam a escola. & $51 \%$ \\
\hline & \multicolumn{2}{|c|}{ Ensino Fundamental: } \\
\hline & $-5^{a}$ Série & $26 \%$ a $30 \%$ \\
\hline & $-6^{a}$ Série & $15 \%$ a $17 \%$ \\
\hline
\end{tabular}

QUADRO 03 - PERFIL DE ADOLESCENTES QUE CUMPREM MEDIDAS SOCIOEDUCATIVAS EM MEIO ABERTO NO DISTRITO FEDERAL.

Fonte: Pesquisa Bibliográfica do trabalho Adolescentes em conflito com a lei: A efetivação da Liberdade Assistida no Distrito Federal. Brasília, 2010.

* Não foram citadas todas as características analisadas na pesquisa bibliográfica e análise documental, mas apenas as informações mais significativas ao nosso problema de pesquisa.

**A variação do percentual referem-se aos anos em estudo da pesquisa bibliográfica: 1999/2000 e da análise documental nos anos 2007 a 2009. Cabe ressaltar que esses valores não são absolutos, e sim aproximativos aos referidos anos em questão. 
O resultado da pesquisa revelou que os adolescentes em cumprimento de medidas socioeducativas em meio aberto são, majoritariamente, do sexo masculino, entre 16 a 17 anos. Em geral, estudam, porém seus estudos com maior frequiência vão até o ensino fundamental, mais precisamente entre a $5^{\mathrm{a}}$ e $6^{\mathrm{a}}$ séries. Vivem em famílias monoparentais, sobretudo com a mãe e a renda familiar gira em torno de 1 a 4 salários mínimos, seguido de renda de menos de um salário mínimo.

No cumprimento das medidas socioeducativas, as que mais se destacam pode ser visualizada na figura a seguir:

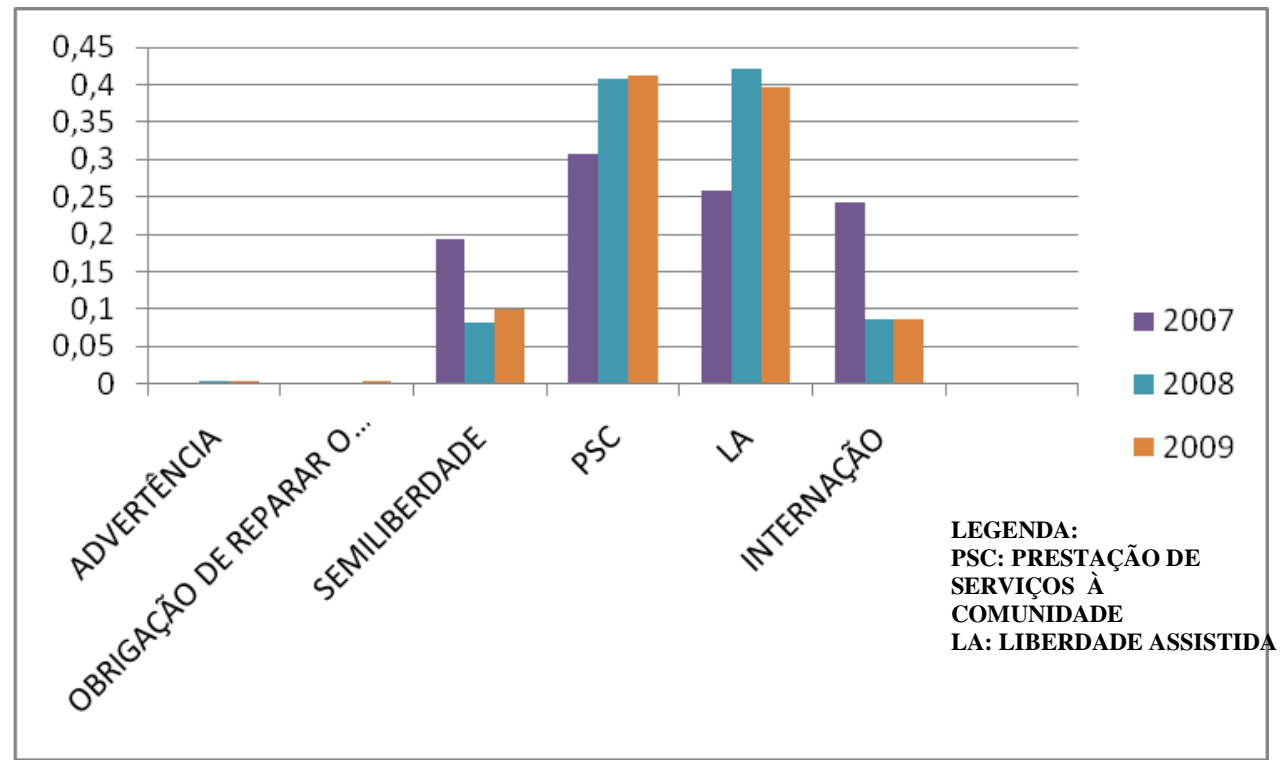

Figura 1 Medidas socioeducativas aplicadas entre os anos 2007 a 2009 no Distrito Federal. Fonte: Análise documental do Trabalho "Adolescentes em conflito com a lei: A efetivação da Liberdade Assistida no Distrito Federal”, realizada na 1ª VIJ/DF, em 2010.

O quadro acima mostra que as medidas socioeducativas de Liberdade Assistida e Prestação de Serviços à Comunidade são as aplicadas com maior freqüência aos adolescentes.

A medida de Prestação de Serviços à Comunidade (PSC) no Distrito Federal pode ser realizada em duas modalidades:

Prestação de Serviços à Comunidade-Convênio (PSC-C): Ocorre quando a SEMSE a partir de convênios firmados entre a VIJ/DF e instituições públicas e privadas, encaminha jovens para cumprir oito horas semanais de trabalho gratuito em período que se estende em até seis meses, conforme sentença judicial. 
$>$ Prestação de Serviços à Comunidade - Doação (PSC-D): Constitui-se na visita e entrega de alimentos, remédios, material de limpeza, entre outros, para as Unidades de Semiliberdade do DF e o Centro de Atendimento Juvenil Especializado (CAJE). Ao entregarem essas doações, os jovens conhecem as dependências dessas instituições e recebem informações a respeito das mesmas. Essa visita é registrada em relatório, no qual o jovem deve descrever o que aconteceu em sua visita, e uma reflexão do delito por ele cometido e o contexto da instituição visitada.

As medidas Socioeducativas podem ainda ser aplicadas de forma cumulativa, pois não há restrição no ECA para que isso aconteça. Abaixo, colocaremos algumas formas de medidas cumulativas em meio aberto que se aplicam no Distrito Federal:

Liberdade Assistida e Prestação de Serviços à ComunidadeConvênio- LA/PSC-C: Quando se acumula a medida de Liberdade Assistida e a modalidade de Prestação de Serviços à Comunidade Convênio.

$>$ Prestação de Serviços à Comunidade-Convênio e Prestação de Serviços à Comunidade-Doação-PSC-C/D: Quando se acumula as modalidades Convênio e Doação da Prestação de Serviços à Comunidade.

> Prestação de Serviços à Comunidade-Doação e Liberdade AssistidaPSC-D/LA: Quando se acumula a modalidade Doação da Prestação de Serviços à Comunidade com a medida de Liberdade Assistida.

O estudo realizado pela $1^{\text {a }}$ VIJ/DF (SILVA,2000) mostra dados sobre a reiteração de ato infracional de adolescentes que cumprem essas medidas socioeducativas em meio aberto como pode ser visualizado a seguir: 
Tabela 1: Medida anterior e Reiteração em 2000

\begin{tabular}{|l|c|}
\hline Medida & Reiteração em \% \\
\hline Liberdade Assistida & 68,5 \\
\hline PSC- CONVÊNIO & 13 \\
\hline PSC-DOAÇÃO & 6,5 \\
\hline LA/PSC CONVÊNIO & 1,8 \\
\hline OUTRAS MEDIDAS OU & 10,2 \\
\hline REMISSÃO & \\
\hline
\end{tabular}

Fonte: SILVA, Marcos Vinícius Lopes da; Silva, Paula Frassinetti Costa da. O Perfil dos jovens atendidos pela SEMSE em 2000. VIJ/DF.SEMSE. Brasília, 2002, p.37.

A figura a seguir, elucidará melhor esses dados:

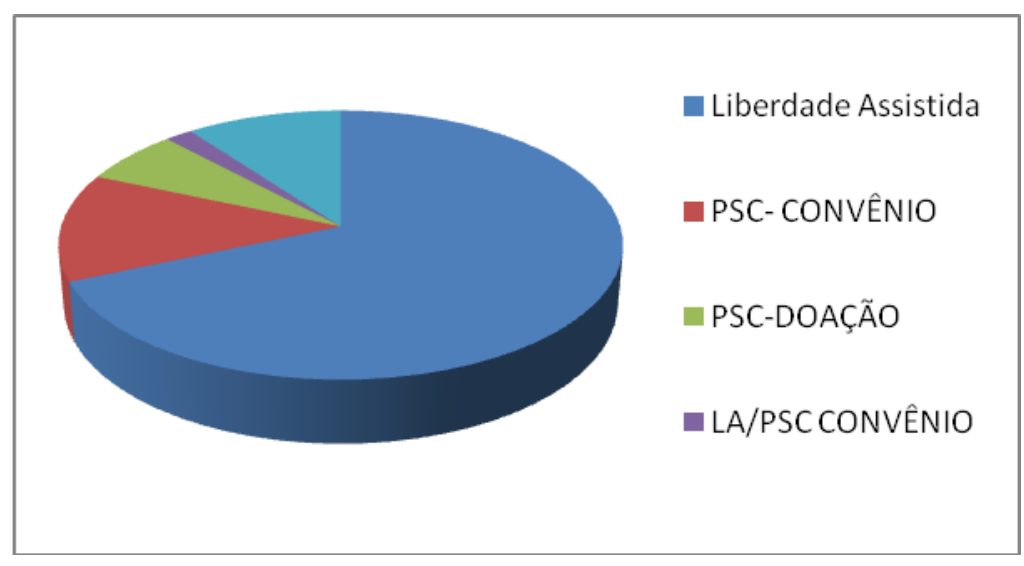

Figura 2:Reiteração do ato infracional

Como pode ser visto, a LA é a medida socioeducativa em meio aberto com maior índice de reiteração, com taxas próximas a $70 \%$. Ela vem também se caracterizando como a medida pela qual o adolescente tem o maior índice de baixa escolaridade.

O relatório de fiscalização no ano 2000 realizado pela SEMSE/DF apontou ainda insuficiência de recursos humanos, sociais e físicos como a principal dificuldade interna para o acompanhamento de jovens que até então era desenvolvido pelos Centros de Desenvolvimento social.

A carência de técnicos, o não fornecimento de passes urbanos e ausência de salas de atendimento, entre outros, vêm interferindo negativamente sobre a qualidade do acompanhamento da clientela específica. Trata-se de adolescentes com altos índices de drogadição, desestimulados para o estudo, por vezes integrantes de gangues e ainda 
discriminados na escola e na comunidade pela condição de estarem em conflito com a lei.

Nesse relatório, os técnicos executores da LA foram unânimes em declarar a inexistência de redes sociais no Distrito Federal capazes de viabilizar ao adolescente o atendimento integral e imediato nas áreas de saúde, do trabalho, esporte e lazer, o que contraria a efetividade de um Sistema de Garantia de Direitos e de uma doutrina de proteção integral presentes no ECA .

Quanto ao Sistema de justiça do Distrito Federal, a VIJ/DF foi colocada como morosa no retorno de suas decisões e o Ministério Público, órgão fiscalizador, distante da realidade dos antigos Centros de Desenvolvimento Social que executavam a LA, hoje função da SEJUS/DF.

Com isso, o parecer técnico do relatório concluiu enfaticamente que "as medidas de Liberdade Assistida e Semiliberdade estão sendo executadas de forma ineficaz não atendendo aos objetivos socioeducativos preconizados pelo ECA, o que resulta no descrédito das medidas por parte do adolescente, da família e da sociedade em geral" (SILVA, 2000). Tal situação, por sua vez, ocasiona o desgaste dos órgãos judiciários e Ministério Público, responsáveis pela aplicação das citadas medidas cabíveis.

Assim, cabe questionar: quais as providências possíveis que se pode realizar para que o ECA e o SINASE sejam efetivamente cumpridos no que se refere à medida de LA? E o que vem a ser a medida socioeducativa de Liberdade Assistida? O próximo tópico esclarecerá seus conceitos, origens, e qual o objetivo da medida empregada ao adolescente em conflito com a lei.

\subsection{A LIBERDADE ASSISTIDA - LA}

A Liberdade Assistida é uma medida coercitiva, adequada à necessidade de acompanhamento da vida social do adolescente, que limita a liberdade e alguns direitos do adolescente, segundo algumas condições impostas, com vista aos seus fins pedagógicos. Sua intervenção educativa manifesta-se no acompanhamento personalizado, na figura de um orientador, a fim de se garantir proteção, inserção comunitária, cotidiano, manutenção de vínculos familiares, frequiência à escola, e 
inserção no mercado de trabalho e/ou cursos profissionalizantes e formativos (VOLPI, 1997).

Sua execução deve ser de preferência em sua comunidade de origem, com prazo mínimo de seis meses, podendo ser prorrogada, revogada ou substituída por outra, ouvido o orientador, o Ministério Público e o defensor (ECA, 1990). Devem ser gerenciados e desenvolvidos pelo órgão executor no nível municipal em parceria com o judiciário. No Distrito Federal, essa medida é executada pela SEJUS/DF em parceria com a SEMSE/DF da $1^{\text {a }}$ Vara da Infância e Juventude do Distrito Federal.

O órgão responsável pela execução do programa deve encarregar-se de apresentar relatórios mensais e avaliações periódicas sobre a inserção do adolescente no programa, suas atitudes comportamentais, responsabilidades, vida escolar, trabalho, situação familiar, e dados complementares, no qual se possa verificar a evolução dessa medida.

$\mathrm{O}$ orientador, nesse caso, deve ter por função, acompanhar, orientar e apoiar ao adolescente, tornando-se um referencial positivo, representando uma figura de autoridade, de pessoa significativa que oferece possibilidades de superação aos obstáculos próprios da realidade em que o adolescente vive (GIUSTINA, 1998).

O programa pode ser desenvolvido ainda, por grupos comunitários com orientadores voluntários, que devem ser capacitados, supervisionados e integrados à rede de atendimento do adolescente.

Geralmente se aplica a LA aos adolescentes reincidentes em infrações consideradas leves, ou para aqueles que cometeram atos infracionais mais graves, mas que, após estudo, verificou-se que para esse adolescente é melhor estar em convívio com sua família. Ou então, para aqueles que cumpriram a medida de privação de liberdade, e após verificar que mantiveram progresso dentro da instituição, retornaram ao convívio da sociedade.

Essa medida trata-se de uma concessão de liberdade, mas sob condições. Seus passos são acompanhados pelo Juiz da infância e da Juventude por meio de pessoas que possuem capacitação profissional. Giustina (1998) diz que essa medida inicia-se com uma audiência de admoestação, na qual o adolescente é apresentado ao seu orientador e são estabelecidas regras para o cumprimento da mesma. A advertência se faz também 
no sentido da necessidade do cumprimento dessas regras, sob pena, inclusive, da regressão da medida.

O SINASE prevê que para o cumprimento da medida socioeducativa de liberdade assistida deve-se estabelecer um processo de acompanhamento, auxílio e orientação ao adolescente. Sua intervenção e ação educativa devem ser estruturadas com ênfase na vida social do adolescente (família, escola, trabalho, profissionalização e comunidade) possibilitando, assim, o estabelecimento de relações positivas que é a base de sustentação do processo de inclusão social desse adolescente (BRASIL,2006).

A legislação do SINASE prevê duas modalidades de Liberdade Assistida: A liberdade assistida Comunitária $(\mathrm{LAC})^{31}$ e Liberdade Assistida Institucional ${ }^{32}$. Para a execução da LA é importante que se mantenha um local específico para a sua execução, contando com salas de atendimento individuais e em grupo, sala de técnicos e demais condições para garantir que a estrutura física facilite o acompanhamento dos adolescentes e seus familiares.

Uma equipe mínima deve ser também composta por técnicos de diferentes áreas do conhecimento, garantindo-se o atendimento psicossocial e jurídico pelo próprio programa ou pela rede de serviços existentes, sendo a relação quantitativa determinada pelo número de atendimentos atendidos.

Cabe às entidades que executam a medida de LA construir uma efetiva rede de atendimento social público e comunitário para encontrar soluções e encaminhamentos das necessidades dos adolescentes e seus familiares. Devem também possuir um plano de marketing social para divulgação do programa nos meios de comunicação com o intuito de agregar novos orientadores.

Fernandes (1998) diz que a gênese da Liberdade Assistida deu-se no conceito de liberdade vigiada, que teve origem em Boston, em 1878, onde o Juiz ou Tribunal nomeava delegados encarregados de verificar e acompanhar a conduta do "menor". Periodicamente deveriam apresentar relatórios podendo até sugerir modificações às medidas impostas, visto que a concepção da liberdade vigiada é uma suspensão da

\footnotetext{
31 Na Liberdade Assistida Comunitária (LAC), cada técnico terá sob seu acompanhamento e monitoramento o máximo de vinte orientadores comunitários, sendo que cada orientador comunitário acompanhará até dois adolescentes simultaneamente.

${ }^{32} \mathrm{Na}$ Liberdade Assistida Institucional (LAI), cada técnico acompanhará, simultaneamente, no máximo vinte adolescentes. Nela entende-se que os técnicos, contratados pela instituição executora, é que fazem diretamente acompanhamento com os adolescentes não existindo a figura do orientador comunitário.
} 
execução da pena privativa de liberdade para manter a pessoa sob vigilância, possibilitando uma analogia com o livramento condicional.

A Liberdade Vigiada aplicada a crianças e adolescentes aparece no Brasil pela primeira vez em 1923. Antes disso, obtinha-se apenas um livramento condicional, no qual a criança ficava sob cuidado apenas do Patronato. Já com a liberdade vigiada houve a possibilidade de ficar em companhia dos pais, responsáveis ou Patronato.

No Código "Mello Mattos", de 1927, por exemplo, as palavras usadas pelo legislador tendiam a considerar a liberdade vigiada como uma medida, ao passo que a internação era usada como uma pena que restringia a liberdade. Desse modo, a medida de liberdade vigiada deixou de ser uma possibilidade restrita ao "menor" internado para qualquer "menor delinqüente ou abandonado", onde a contravenção ou delito desses “menores” culpabilizava a família, como já visto anteriormente.

O termo Liberdade Assistida passou a ser utilizado no novo código de menores, de 1979, e tinha o objetivo de "vigiar, auxiliar, tratar e orientar o menor" (FERNANDES, 1998, p.125). Era caracterizada como uma medida aplicável ao "menor" em situação irregular como resultado de um processo judicial, sendo, pois, imposta por sentença.

A Liberdade Assistida tinha, diferentemente da Liberdade Vigiada, um conceito não apenas de vigiar, mas também amparar, pois se reconheceu que apenas vigiar o "menor" não garantia a sua ressocialização, sendo necessária também a utilização dos recursos da comunidade, através de clubes de serviço, grupos religiosos, organizações de bairro e de particulares, que podem ser encarregados pelo Juiz de ministrarem a assistência à criança, visando a sua integração familiar e comunitária.

A LA nessa época era uma medida que cerceava a liberdade mediante condições a serem observadas que interferem no comportamento, no modo de viver da pessoa. Tais condições ou regras eram: apresentar-se regularmente ao serviço encarregado da execução da medida, não mais praticar atos infracionais, freqüentar a escola e/ou ensino profissionalizante, trabalhar, chegar cedo em casa, enfim, não permanecer na rua em estado de "ociosidade" (FERNANDES, 1998). As condições impostas ao "menor" em liberdade assistida eram de seu conhecimento, assim como de seus pais ou responsável, os quais em audiência firmavam um compromisso ou termo de liberdade assistida. 
Com o advento do Estatuto da Criança e do Adolescente, a LA não se aplica mais ao "menor" com "desvio de conduta", expressão, aliás, que inexiste no ECA, bem como a exclusão dos termos vigilância e tratamento. $\mathrm{O}$ adolescente passa a ser não mais entendido como objeto de vigilância e controle, mas como sujeito livre e em desenvolvimento, que requer apoio e assistência no exercício de sua liberdade, para se desenvolver em plenitude.

Por sua natureza, considera-se importante que ela se realize com o maior grau possível de voluntariedade e protagonismo do adolescente, para apoiá-lo primordialmente na construção de um projeto de vida.

As medidas de Liberdade Assistida e prestação de serviços à comunidade são consideradas, por alguns críticos, como as mais eficientes e eficazes das medidas preconizadas pelo ECA. A defesa sobre aplicação dessa medida parte, entre outros argumentos, do fato de que essa medida pode ter a capacidade de reconstruir no adolescente a sua atividade, seus valores, a sua convivência familiar, social, escolar e profissional, além de o adolescente continuar em seu "mundo natural", isto é, família e sociedade. Ela pode facilitar ao adolescente a construção de um novo projeto de vida, norteador de suas atitudes e da sua escala de valores.

No entanto, a Magistrada Conceição A. Mousnier (1991) adverte que:

O tratamento em meio aberto é o ponto nevrálgico do sistema de atendimento ao adolescente infrator. A falência do programa de execução de medida de liberdade assistida é a porta aberta para a reincidência, o aprofundamento do processo de marginalização, e, por fim, tornando imperiosa a aplicação da medida extrema de internação (MOUSNIER, 1991 apud FERNADES, 1998).

Verificou-se, por meio da análise documental, que o trabalho sócio-educativo de liberdade assistida nem sempre alcança o êxito desejado. O "sucesso" da Liberdade Assistida depende em muito dos recursos advindos dos órgãos competentes para a sua efetivação através do SINASE. Contudo, a falta de êxito que acontece na efetivação da LA não pode ser explicada apenas com a falta de recursos ou falta de interesse por parte dos governantes.

Existem razões para essa aparente ausência de boa vontade. Além da demora no início do cumprimento da medida que pode contribuir para a ocorrência da reiteração de atos infracionais, sabe-se que o país tem vivido ao longo dos anos, uma situação de 
descaso e descontinuidade na formulação de políticas públicas e sociais e ações em relação à atenção à criança e ao adolescente.

O desmonte das políticas sociais e a crise de legitimidade das instituições de atendimento a esse segmento da população contribuem para que a inscrição dos direitos conquistados na Constituição de 1988 não garanta a sua efetiva materialização (CARVALHO, 2001 apud FUCHS, 2004). A razão para o descaso na formulação de políticas públicas será visto com mais detalhes no próximo capítulo.

\section{CAPÍTULO 4: A LIBERDADE ASSISTIDA NO DISTRITO FEDERAL E OS REFLEXOS DA CONTRA-REFORMA BRASILEIRA}

Os relatórios e a análise documental apresentada no capítulo 3 apontaram, dentre outras coisas, a insuficiência de recursos humanos, sociais e físicos como a principal dificuldade interna para o acompanhamento de jovens em cumprimento da medida socioeducativa de Liberdade Assistida. Apontaram-se também problemas como a insuficiência de recursos humanos e financeiros para o acompanhamento da medida, bem como inexistência de redes sociais que viabilizem o atendimento adequado aos adolescentes.

Além dos dados apontados na pesquisa bibliográfica e na análise documental, sabe-se que em 2007 durante uma fiscalização, a Promotoria de Justiça de Defesa da Infância e da Juventude do Distrito Federal concluiu que não há estrutura suficiente para atender todos os adolescentes que cumprem esse tipo de medida socioeducativa. ${ }^{33}$

Existem 14 unidades de Liberdade Assistida no Distrito Federal. No início do ano de 2007, o governo do DF retirou da Secretaria de Estado de Desenvolvimento Social e Transferência de Renda (SEDEST) a responsabilidade pelo acompanhamento dos jovens e passou a demanda à Secretaria de Justiça e Cidadania (SEJUS). Houve também reportes de insuficiência de recursos para a Liberdade Assistida.

Reportagens ${ }^{34}$ mais recentes também noticiaram a falta de recursos no tocante à efetivação dessa medida socioeducativa:

\footnotetext{
${ }^{33}$ DF: Liberdade Assistida está abandonada. Jornal do Brasil, Rio de Janeiro. 12/12/2007. Disponível em: 〈http://www.comunidadesegura.org/en/node/37701 >. Último Acesso em 10/08/2010.

34 Klingl, Erika. O gargalo da ressocialização. CORREIO BRAZILIENSE. Distrito Federal. 13/07/2009.Disponível em: <http://www.correiobraziliense.com.br/app/noticia182/2009/07/13/cidade,
} 
É unânime entre os especialistas e atores dos direitos da infância e adolescência a opinião de que o principal gargalo do Estatuto da Criança e do Adolescente (ECA) está na aplicação de medidas de recuperação para meninos e meninas que estão em conflito com a lei.

A promotora de Justiça de Defesa da Infância e da Juventude entrevistada Luísa de Marillac - diz que o motivo seria a falta de estrutura da Justiça e do sistema de aplicação de medidas de responsabilização. No DF, por exemplo, existem apenas duas instâncias judiciárias para o atendimento à infância e adolescência, sendo que a VIJ de Samambaia tem atribuição apenas para julgar atos infracionais.

Viu-se também que, para a Liberdade Assistida, a insuficiência de estrutura e recursos figuram como um dos principais problemas para a execução dessa medida, e a falta de estrutura não reside apenas no sistema judiciário, mas também nos órgãos de execução. A promotora aponta ainda que

(...) a realidade aparece em números. Nada menos que $85 \%$ das medidas de internamento - provisórias ou não - no Centro de Atendimento Juvenil Especializado (Caje) resultam em reincidência $(\ldots)$

Na Liberdade Assistida, essa taxa de reincidência chega a quase $70 \%$, o que faz acreditar que esse problema não é pontual de uma medida ou outra, ou que é decorrente das medidas em si, mas sim que a execução e efetivação tem se dado de maneira insuficiente. Marillac acrescenta que:

(..)Por falta de estrutura para outras medidas socioeducativas, como a liberdade assistida, quando há responsabilização, ela vem na forma de internação.

Nesse aspecto podemos corroborar a idéia que uma não efetividade das medidas socioeducativas em meio aberto, acarreta um aumento no número de internações. Esse processo parece funcional ao sistema neoliberal, uma vez que "esconde" as fragilizações

$\mathrm{i}=125894 /$ RESSOCIALIZACAO+E+PRINCIPAL+GARGALO+DO+ECA.shtml>. Último acesso em $10 / 08 / 2010$. 
caracterizadas pelos desmontes das políticas sociais. Pereira (2001) bem discursa sobre isso, quando diz que no Brasil há uma questão social latente, que precisa ser explicitada.

Em outra reportagem com o então subsecretário de Justiça do Governo do Distrito Federal (GDF) e defensor público, João Marcelo Feitosa, ele defende que "(..) O problema do sistema é que é muito dispendioso e a implantação é mais morosa (...)”.

No parecer do defensor, o motivo que ocasiona uma não adequada execução das medidas reside nos altos custos para a implementação desse sistema de atendimento. $\mathrm{O}$ SINASE, que entrou em vigor em 2006, até hoje tem encontrado dificuldades e resistências na sua implementação. Nos anos de 2009 e 2010 até foram abertos concursos públicos para preenchimento de vagas em postos de trabalho para a execução dessas medidas, mas isso não altera o fato de que as estruturas e condições de trabalho permanecem precárias, e, pior, dependentes da atuação de uma determinada política de governo, quando as disposições consoantes no SINASE fazem parte de uma política de Estado.

Além disso, parece-nos ingênuo pensar que essa precarização advém apenas de falta de recursos, pois como diz Netto apud Duarte (2008, p.5):

O tratamento contemporâneo da questão social despolitiza seu reconhecimento na realidade brasileira como expressão das relações de classe nesta sociabilidade, visto que retira do Estado a responsabilidade histórica com as seqüelas sociais originárias do modo de produção capitalista. Constituem-se em 'ações minimalistas para enfrentar uma questão social maximizada'

E também em Montaño (2008, p.156) vemos que

A ineficiência estatal, sua corrupção e até seus déficits fiscais se devem, em grande medida, ao uso do Estado para interesses privados do capital: o clientelismo eleitoral, o financiamento de obras necessárias à industrialização, os créditos a (quase) fundo perdido para o capital, as compras de votos para projetos governamentais.

O defensor público reconhece, no entanto, que o ECA trouxe avanços, como o aumento das unidades de internação de uma para quatro, mas no que diz respeito às unidades de liberdade assistida e semiliberdade, argumenta que o avanço foi tímido, já 
que existem apenas 14 unidades de liberdade assistida, quando deveria haver uma unidade para cada região administrativa ${ }^{35}$, e apenas três unidades de semiliberdade.

A nosso ver, o avanço em número das unidades de internação, ao passo que o crescimento das demais unidades de medidas socioeducativas foi praticamente insignificante, não é mera coincidência.

Ao longo dos anos, a população carcerária brasileira cresce em média $10 \%$ ao ano $^{36}$. Wacquant $(2007)^{37}$ também registra essa tendência em outros países, como um fenômeno que ele denomina "Erupção do Estado Penal", cuja repercussão prática e ideológica advém, sobretudo, das reformas que as sociedades foram submetidas com o advento do neoliberalismo.

No Distrito Federal, quanto ao trato do adolescente, vimos que a tendência é diferente, pois a internação como medida socioeducativa tem diminuído ao longo do tempo (vide figura1) ao passo que as medidas de Liberdade Assistida e Prestação de Serviços à comunidade, têm aumentado. Porém, como já se viu esta é sem estruturas e recursos adequados. E isso causa uma inquietação: Seria também essa precarização, e falta de acesso adequado no tocante à Liberdade Assistida uma "armadilha" para se punir mais uma vez?

Acreditamos que a precarização dessas políticas de atendimento aos adolescentes autores de ato infracional seria mais uma estratégia neoliberal para deslegitimar e reforçar a "inoperância” do Estado frente à responsabilidade das Políticas Sociais.

Segundo Tejadas (2008) a execução de uma medida apontada como ineficaz, além de resultar no descrédito das medidas por parte do adolescente, da família e da sociedade em geral, e ocasionar o desgaste dos órgãos competentes na aplicação e

\footnotetext{
35 O DF subdivide-se em 30 regiões administrativas, como segue: Brasília, Gama, Taguatinga, Brazlândia, Sobradinho, Planaltina, Paranoá, Núcleo Bandeirante, Ceilândia, Guará, Cruzeiro, Samambaia, Santa Maria, São Sebastião, Recanto das Emas, Lago Sul, Riacho Fundo, Candangolândia, Lago Norte, Águas Claras, Riacho Fundo II, Sudoeste/Octogonal, Varjão, Park Way, Setor Complementar de Indústria e Abastecimento, Sobradinho II, Jardim Botânico, Itapoã, Setor de Indústria e Abastecimento e Vicente Pires.

${ }^{36}$ Anotações da Plenária Estado Penal, criminalização da Pobreza e do Trabalho do/a Assistente social, realizada no XIII Congresso Brasileiro de Assistentes Sociais, realizados entre os dias 31 de julho a 05 de agosto. Palestrante Marcelo Freixo (Comissão de Defesa Dos Direitos Humanos e Cidadania da ALERJ).

${ }^{37}$ Op cit: Wacquant, Loïc. Punir os pobres: A nova gestão da miséria nos Estados Unidos [A onda punitiva]. $3^{a}$ edição revista e ampliada. Instituto Carioca de criminologia. Editora Revan. Rio de Janeiro, 2007.
} 
execução das medidas, evidencia que o descontinuísmo nas execuções de ações em relação à atenção à criança e ao adolescente contribui para a reincidência dos atos infracionais.

Esses descontinuísmos, problematizados anteriormente no capítulo 2, faz parte dos desmontes dos direitos conquistados, conformando-se à lógica das Reformas neoliberais, no qual se concentra cada vez mais o capital, e se fragmenta o social.

Assim, ao invés de se evoluir para uma estratégia no sentido de se constituir uma rede universal de proteção social que explicite o dever do Estado na garantia dos direitos sociais, retrocedemos a uma concepção de Estado que apenas tenta complementar as políticas sociais, e não se responsabilizar efetivamente.

É fato que se criou o SINASE como uma tentativa de padronizar e normatizar os procedimentos para a adolescência em conflito com a lei. Mas a efetivação dessa política no DF, até agora, passados quatro anos, ainda não se consolidou. Há um grande interesse do capitalismo contemporâneo para que estas políticas não se viabilizem. Entretanto, é necessário considerar que há também lutas da sociedade para que ocorram as políticas para os adolescentes com mais qualidade. Uma delas é a luta para a contratação imediata de mais profissionais concursados para o setor de medidas socioeducativas, além da mobilização de vários segmentos sociais em consonância com a luta em defesa dos direitos da Criança e do Adolescente, como o CEDECA/DF ${ }^{38}$, local do nosso estágio supervisionado, denunciando as precarizações do sistema de atendimento socioeducativa.

Diante dessa análise, nossa hipótese pode ser confirmada de que a medida socioeducativa de Liberdade Assistida no Distrito Federal aplicável aos adolescentes em conflito com a lei, através da política pública regida pelo Sistema Nacional de Atendimento Socioeducativo - SINASE, não está sendo efetivada de acordo com seus parâmetros regulatórios. Isso porque há um contexto de avanços e retrocessos existentes na passagem de um Estado social, figurado principalmente nas conquistas democráticas de 1988, a um Estado penal, na qual Wacquant (2007) diz que criminalizam, sobretudo, a pobreza.

Nossa conclusão a esse respeito gira em torno dos seguintes fatores evidenciados ao longo deste estudo: A consonância do modelo de Liberdade Assistida de acordo com

\footnotetext{
${ }^{38}$ Centro de Defesa dos Direitos da Criança e do Adolescente.
} 
o modelo de Estado neoliberal, a reincidência de atos infracionais como negação da efetividade do próprio Sistema de Atendimento, a agudização da questão social no tocante ao trato da questão da infância e adolescência e a criminalização da pobreza, com responsabilização do indivíduo com o advento de um Estado Penal. Estas questões serão colocadas com maior profundidade nos próximos itens.

\subsection{O modelo de contra-reforma do Estado nas políticas de atendimento socioeducativo}

Com o advento da Contra-Reforma Brasileira viu-se que há uma redução do poder público em áreas estratégicas, como a área social. Percebe-se muitas vezes que o investimento na área de segurança, por exemplo, é feito para quem está fora das "prisões" e não para quem está "dentro" dela 39 .

Urge, assim, a necessidade de ampliação da participação popular com vistas a exercer pressão à ordem vigente, para a manutenção e garantia de todos os direitos conquistados e a conseqüente outorga de direitos sociais expressados pela Constituição Federal de 1988, a qual para a infância e adolescência se concretizou no ECA.

Para isso, Tejadas (2008, p.45), afirma que alguns desafios precisam ser enfrentados, com enfoque à superação dessas dificuldades:

\section{A democratização da política por meio de participação popular nos}

Conselhos de Direitos, pois segundo a autora, há uma raiz profunda de cidadania tutelada e supervalorizada na ação do Estado, na figura, ou de um ente repressor, ou de um distribuidor paternalista de empregos e favores, sem tradição de participação, fazendo com que os espaços de organização tornem-se meios de articular apenas os interesses de determinados grupos.

\footnotetext{
39 A citação aqui das prisões foi proposital, uma vez que embora o adolescente cumpra medidas socioeducativas, reforça-se, ainda, uma lógica prisional, onde o Estado tende a se tornar visível apenas na esfera da criminalização.
} 
Necessidade de atuação dos municípios onde, de fato, os recursos destinados às políticas públicas na área da infância e juventude são canalizados para o Fundo dos Direitos da Criança e do Adolescente e deste destinados às políticas prioritárias. Na opinião da autora "faz-se necessário um novo tipo de atuação do Estado, nos quais as políticas públicas estejam articuladas entre si, superando a fragmentação presente nas ações estatais no Brasil" (ibidem).

Acrescentamos aqui uma tentativa de ruptura com a vigente ordem capitalista. Contudo, Montaño (2008, p.19) alerta que a transformação social, revolucionária, requer condições objetivas (estruturais e conjunturais, lutas sociais) e subjetivas (consciência de classe para si, organização). Para o autor, resulta tão equivocado pensar que apenas as contradições imanentes à dinâmica do capital e suas crises irão derivar, como que naturalmente, no desmoronamento do sistema capitalista, como é errado pensar que só a intencionalidade de indivíduos e grupos subalternizados transformará a sociedade. A luta da classe trabalhadora é imprescindível, uma vez que Montaño nos ensina que há necessidade de articulação das lutas sociais gerais, sem perder de vista a centralidade nas contradições das classes sociais, e que perpassam todas as arenas de lutas: Estado, mercado, indústria, sociedade civil.

Os projetos de enfrentamento ao neoliberalismo e os projetos de superação da ordem capitalista confrontam-se hoje num convulsionado processo heterogêneo de lutas sociais. A riqueza desse processo heterogêneo não pode ser sintetizada apenas na rubrica "lutas da sociedade civil", mas também não pode ser recuperada excluindo as lutas diversas heterogêneas, na sociedade civil.

Assim, a articulação das lutas sociais de forma geral, com a centralidade de classe, surge como a única perspectiva para apreender tal riqueza e como o caminho da verdadeira transformação, no enfrentamento ao neoliberalismo e na superação da ordem vigente. 


\subsection{A reincidência do ato infracional}

Um grande desafio que precisa ser enfrentado é a questão da reincidência do ato infracional de adolescentes que estiveram em cumprimento da medida de Liberdade Assistida. Só no Distrito Federal a análise documental constatou que a taxa de reiteração do ato infracional é de quase $70 \%$.

Tejadas (2008) identifica nesse contexto: 1) a construção de uma vulnerabilidade, baseada primeiramente na ausência de um projeto societário capaz de incluir a todos; 2) a ausência de possibilidade de acesso ao trabalho, como elemento integrador socialmente consagrado; 3) fragilidade do suporte comunitário e familiar, que faz com que o adolescente constantemente tenha uma vivência de "nãopertencimento". Para a autora, nessa dinâmica, a prática do crime e a vinculação aos grupos com ele identificada colocam-se como meios de pertencer, repercutindo na reincidência.

Outro aspecto apontado por Tejadas (2008) é a invisibilidade da juventude em situação de vulnerabilidade nas políticas sociais públicas. Esta é identificada por meio do não-acesso às políticas ou da desqualificação destas quanto ao reconhecimento do sujeito e à produção de respostas adequadas.

Nesse sentido, "a ausência ou inadequação do Estado inviabiliza a construção de estruturas de sociabilidade portadoras de sentido, as quais possibilitariam aos adolescentes condições de projetar um futuro e de pertencer a uma estrutura societária" (TEJADAS, 2008, p.234).

Os impactos da questão social sobre esses adolescentes são compreendidos pelos mesmos como sinais de "incompetência", "incapacidade", "desajustes", "patologias", dentre outras coisas, fruto da ausência de vínculos e de proteção. Como já foi visto no decorrer deste trabalho, esse caminho vem sendo adotado na sociedade capitalista globalizada. Não se nega aqui a esfera da subjetividade, mas sabe-se que a compreensão desse processo abarca o modo de produção capitalista e a forma como cada sujeito é inserido nessa ordem social.

O Distrito Federal não está imune aos impactos do neoliberalismo no que tange à retração dos gastos públicos e suas consequiências quanto às políticas públicas. Embora tenha havido a participação popular para uma ampliação das políticas sociais, o fato é 
que ainda há uma ausência, descontinuidade e desqualificação das políticas públicas para a produção e a reprodução da incidência.

No que tange ao Sistema de Atendimento ao adolescente autor de ato infracional, Tejadas (2008) afirma que a face mais explícita está ainda concentrada na esfera punitiva. Assim, o Sistema que deveria contribuir para a redução da incidência, acaba por reforçá-la. A finalidade educativa, por sua vez, pareceu submergir a uma estrutura e forma de operacionalizar as medidas que estão impregnadas da visão tutelar ou punitiva. Segundo a autora, os meios coercitivos encontrados para o meio aberto voltam-se à ameaça de sua regressão para o meio fechado ou a apresentação do adolescente à autoridade judiciária.

Diante disso, o caráter da medida ganha destaque e, nesse, o tempo de cumprimento da medida. Reconhece-se até possibilidades na Liberdade Assistida, mas as descontinuidades das ações constantemente permeiam a passagem do meio fechado para o meio aberto, no qual não se efetivaram estratégias de vinculação do adolescente às novas equipes ou continuidade das ações iniciadas na privação de liberdade, e viceversa. O acesso a alguns serviços é oferecido em determinado período, e logo, em seguida, sofre interrupção.

Todas essas características acabam, assim, por reforçar mais a questão punitiva, e o desafio que se impõe a isso, ainda vinculado ao campo da proteção dos direitos.

\subsection{A punição e repressão ao adolescente como reflexo da ideologia neoliberal.}

Outra característica perpassada pela ideologia neoliberal é o surgimento de um Estado Penal. Na passagem de um modo de regulação estatal, na tentativa de consolidação de um Estado Social figurado na Constituição de 1988, para um contexto contemporâneo do capitalismo global, desregulado e altamente competitivo, nasce o Estado penal máximo.

Potyara Pereira (2009) esclarece que a acumulação do capital não dispensa a segurança institucional e legal do Estado para administrar não apenas riscos e incertezas inerentes ao processo de acumulação, mas para conter conflitos de classe e arbitrar desavenças competitivas entre diferentes facções do próprio capital. Em toda parte há uma preocupação com a segurança. O repentino aparecimento da preocupação com a segurança que atinge a maior parte dos países pós-industriais desde o final do século 
XX constitui uma reação, um desvio e uma negação à generalização da insegurança social e mental produzida pela "difusão do trabalho assalariado dessocializado" 40 (WACQUANT, 2007, p.15).

Em uma sociedade onde a lógica do mercado a divide entre possuidores, consumidores e destituídos, sobra uma grande massa de brasileiros que são destituídos de significado, com a perda também de uma dignidade que vai muito além do desemprego. Há uma concepção de empreendedorismo que, exacerbada mundialmente na concepção capitalista, integra um atendimento social em troca de qualquer trabalho, sacrifícios ou expiações de culpa, denominada Workfare. Este, na verdade, não visa o atendimento de necessidades humanas, mas sim num mercado de trabalho de curto prazo e socialmente desprotegido, para atender as necessidades do capital.

Além disso, Pereira (2009, p.229) diz que a ativação dos desempregados para se inserirem no mercado de trabalho funciona como punição; põe em risco o direito dos pobres à assistência pública, já que tal assistência pode ser suspensa caso o assistido se recuse a aceitar o trabalho que lhe é imposto. Há também presente um alto grau de flexibilidade do mercado de trabalho, cujo preço é a marginalização.

Vinculadas a esse processo, há uma substituição do discurso do direito pelo discurso do mérito. E assim, a culpa em geral recai em uma irresponsabilidade e imoralidade pessoais, ou seja, há cada vez mais uma culpabilização do indivíduo e uma desresponsabilização do Estado.

A situação das políticas aplicáveis à criança e ao adolescente na contemporaneidade não foge a essa análise. Ao se prestar atenção tanto à dinâmica sócio-econômica quanto à discursiva em ação no elo cada vez mais forte entre as renovadas políticas de bem-estar e penal, têm-se os meios para constatar que o explosivo crescimento do alcance e da intensidade da punição, está intrinsecamente relacionado à estrutura de classes e à desregulamentação econômica.

$\mathrm{O}$ encarceramento serve, assim, para

neutralizar e estocar fisicamente as frações excedentes da classe operária, notadamente os membros dos grupos despossuídos

\footnotetext{
${ }^{40}$ Dessocializado se refere ao trabalho assalariado flexibilizado, precarizado e mal remunerado, como uma tentativa de desmontar as conquistas e os direitos conquistados pelas lutas históricas dos trabalhadores, isto é, age contra o nível das estruturas e dos mecanismos coletivos que as produzem e as reproduzem.Cf: Wacquant, 2007, p.20.
} 
estigmatizados que insistem em se manter em rebelião aberta contra seu ambiente social (Wacquant, 2007, p.16)

Os adolescentes em especial, são uma parte dessa população estigmatizada, tanto que há uma corrente e projetos de lei que insistem em reduzir a maioridade penal para atingir essa finalidade.

Assim, ao analisar a punição e repressão como estratégia empregada nesse Estado que criminaliza e penaliza a pobreza, temos que levar em consideração, em conjunto, as dimensões materiais e simbólicas da reestruturação contemporânea da punição, no qual o neoliberalismo em ascensão provoca modificações nas políticas sociais para uma transição a políticas penais.

O crime e a punição, assim, fazem parte de uma reformatação do Estado na era da ideologia hegemônica do mercado, pois a expansão penal encerra, no fundo, um projeto político, um componente central da remontagem da autoridade pública, necessária para alimentar o avanço do neoliberalismo.

\subsection{A questão social presente na prática do ato infracional}

Nesse ínterim, a questão social passa a ser objeto de um violento processo de criminalização que atinge as classes subalternas. Recicla-se a noção de "classes perigosas" sujeitas à repressão e extinção.

Há também uma tendência de naturalizar a questão social, que é acompanhada da transformação de suas manifestações em objeto de programas assistenciais focalizados de "combate à pobreza" ou em expressões da violência dos pobres, cuja resposta é a segurança e a repressão oficiais. Evoca o passado, quando era concebida como caso de polícia, ao invés de ser objeto de uma ação sistemática do Estado no atendimento às necessidades básicas da classe operária e outros segmentos trabalhadores.

$\mathrm{Na}$ atualidade, as propostas imediatas para enfrentar a questão social no país articulam assistência focalizada com repressão. Apresenta-se um braço coercitivo do Estado em detrimento da construção do consenso necessário ao regime democrático.

Com isso, há uma fragmentação das questões sociais, atribuindo unilateralmente aos indivíduos a responsabilidade por suas dificuldades. Os "problemas sociais" 
aparecem como problemas do indivíduo isolado, perdendo-se a dimensão coletiva e isentando a sociedade de classes da responsabilidade na produção das desigualdades sociais.

Iamamoto (2001) confirma a idéia de se tentarem analisar essa questão com um discurso genérico, o que redunda em uma visão unívoca e indiferenciada da questão social, prisioneira das análises estruturais, segmentadas da dinâmica conjuntural e da vida dos sujeitos sociais.

A questão social passa a ser esvaziada de suas particularidades, perdendo o movimento e a riqueza da vida, ao se desconsiderar suas expressões específicas, que desafiam a "pesquisa concreta de situações concretas" (IAMAMOTO, 2001). Esta vem, ao longo do tempo, atrelada apenas à pobreza, perdendo, muitas vezes seu estatuto teórico, fundamentada na luta de classes.

Ao longo dos anos viu-se que o combate à criminalização, foi na verdade, em todo o tempo, uma tentativa de criminalizar a pobreza. Retoma-se, muitas vezes, ainda hoje a noção de “classes perigosas". Essa "classe perigosa” provém no imaginário social de um discurso de produção do medo, o que possibilita o funcionamento desse Estado Penal.

Há um pólo de responsabilização ao indivíduo descolada da trama das relações sociais perversas que permeiam esse sistema capitalista, pois a totalidade do capital age hoje como se não houvesse apropriação e expropriação.

Contra isso, é que esta pesquisa localizou o objeto de estudo na sua forma geral, mas também o contextualizou na sua particularidade, identificando, assim, como a questão social perpassou o trato da infância e adolescência na efetivação da Liberdade Assistida no Distrito Federal. 


\section{CONSIDERAÇÕES FINAIS}

Analisar como se dá a efetivação da Liberdade Assistida no Distrito Federal dentro dos diversos contextos da sociedade capitalista, sob a égide de uma contrareforma do Estado Brasileiro foi importante para a compreensão do tratamento dispensado a esta parcela populacional, em especial aos adolescentes em conflito com a lei, cuja intervenção ainda tem resquícios de uma doutrina correcional-repressiva.

Com o advento do ECA (1990), houve uma quebra de paradigma. A criança e o adolescente passaram a ser reconhecidos como sujeitos de direitos e não como menores em "situação irregular" por culpa própria ou de seus familiares. A família passou a ser considerada como aqueles que podem e devem orientar a criança e o adolescente, mas não "moldá-los", pois são pessoas com singularidades próprias e maneiras particulares de pensar.

O conjunto de direitos conquistados na Constituição de 1988 e no ECA avançou consideravelmente em direção a um Estado Social. Percebe-se, entretanto, que nos últimos anos tem havido uma tendência dos países submeterem-se a uma lógica de ajuste fiscal, fruto de um contexto neoliberal que restringe o acesso universal a bens de consumo coletivo e aos direitos sociais. Estas transformações estão situadas em uma contra-reforma do Estado, na expansão do "terceiro setor", e no redirecionamento dos gastos públicos, o que traz características diferenciadas quanto às políticas sociais, em cujo o formato se desenham às necessidades de acumulação capitalista.

Nesse contexto, há também uma tendência de fragmentação das políticas sociais que também pode ser identificada a partir do crescimento do chamado "terceiro setor", particularmente no crescimento das Organizações Não-Governamentais (ONGs). Desenvolve-se, assim, um papel ideológico claramente funcional aos interesses do capital no processo de reestruturação neoliberal, promovendo-se a reversão dos direitos e das políticas sociais e assistenciais universais de qualidade a políticas mercantilizadas, fragmentadas e focalizadas. Deste modo, o enfrentamento da Questão Social no Brasil acaba por ser assumido, cada vez mais, pelas entidades do "terceiro setor", que recebem financiamento do próprio Estado para execução das ações, programas e projetos. 
Essa dinâmica societária contribui para a mistificação da idéia de "sociedade civil" como um representante homogêneo dos interesses populares, em oposição ao Estado e ao mercado, supostamente tidos como representantes oriundos do capital. Assim, justifica-se o debate sobre o "terceiro setor" nas Políticas de Atendimento à infância e adolescência, pois, segundo Montaño (2008), este se constitui numa ferramenta importante para o enfrentamento do processo neoliberal de alteração da modalidade de trato à "questão social".

Observou-se que o Distrito Federal segue esta lógica em que o Estado atende mais às necessidades do capital em detrimento às necessidades sociais, sucateando os espaços de destinação públicos, e privilegiando as terceirizações de serviços que deveriam ser fornecidos pelo Estado.

As políticas de atendimento ao adolescente autor de ato infracional não foge à regra do bombardeio de precarização das políticas públicas. Os adolescentes que cumprem as medidas socioeducativas de Liberdade Assistida, em geral, são pessoas advindas de famílias que tiveram seus direitos violados ou em risco de o serem, e de baixa renda. E o caminho que se toma é punir a pobreza, ao invés de se investir em atuações contra a mesma. Este é um tipo de gestão que persiste em criminalizar a questão social e suas expressões.

Além disso, não se verifica no Distrito Federal a observância do que está disposto no SINASE e no ECA para o cumprimento dessa medida socioeducativa. A insuficiência de estrutura e recursos é apontada como um dos principais problemas apresentados, e o resultado disso é que se constatam falhas no efeito ressocializador do adolescente, o que contribui, dentre outros aspectos, para a L.A figurar entre as medidas que possuem o maior índice de reiteração de ato infracional, chegando essa taxa a quase $70 \%$.

E assim, muito embora seja apontada por muitos autores como uma medida de grande eficácia, se executada adequadamente, sabe-se que a falta de redes que viabilizam o atendimento integral do adolescente que cumpre a L.A reforça a ideologia da contra-reforma no Distrito Federal, o que gera um descrédito na aplicação dessa medida não somente por parte da sociedade, mas também da família e do próprio 
adolescente, o que é funcional a lógica neoliberal no sentido de se desmontar a doutrina da proteção integral aplicável ao SINASE.

Diante disso, seria a desestruturação dessa política de atendimento uma via para se punir mais uma vez? Acreditamos que sim, pois através de uma análise da totalidade, vimos que a erupção do Estado penal na atualidade é funcional à lógica do capitalismo contemporâneo, contribuindo com a persistência de: 1) uma cultura de institucionalização de crianças e adolescentes, através de uma cultura asilar correcional; e, 2) estereótipo do pobre que deve ser educado e corrigido pelo Estado a partir de uma perspectiva prisional.

Constatou-se ainda a ideologia da criança e do adolescente pobre como potencial "marginal", articulada a medidas e políticas que tendem a ser encaradas como salvação, seja através do trabalho ou da institucionalização no cotidiano das ações voltadas para a juventude. Com isso há também a persistência da forma autoritária e policialesca no trato com o adolescente. E, por maior que tenha sido o esforço e a mobilização para a construção de um novo marco legal, os direitos estabelecidos pelo ECA ainda convivem com uma perspectiva conservadora, a qual atribui o abandono e a negligência à própria vítima que, em geral, é submetida a situações de violência.

Sendo assim, talvez o primeiro passo seja reforçar na sociedade a concepção da criança e do adolescente como sujeitos de direitos, ou seja, fazer com que o seu direito seja efetivado pelo fato de serem pessoas humanas, dignas de todo respeito e consideração, independente das motivações. No cerne desse entendimento está a importância desse debate para o serviço social que reconhece nos princípios fundamentais do seu código de ética (1993) a defesa intransigente dos direitos humanos e recusa do arbítrio e do autoritarismo, além de seu dever de empenhar-se na viabilização dos direitos sociais dos usuários, através dos programas e políticas sociais.

A atuação do Serviço social pode estar presente também na luta contra esta separação radical que se faz aos aspectos políticos, econômicos e sociais que compõem o Estado e a Sociedade na atuação da defesa dos direitos dessa parcela infanto-juvenil, na qual se verifica uma desarticulação dos nexos mais profundos do todo social, sendo necessário o resgate da perspectiva de totalidade na intervenção da questão da infância e adolescência. 
Percebe-se, porém, que, individualmente, não se conquista nada. Somos sujeitos coletivos, e assim, os direitos devem ser coletivos, e produzidos coletivamente. E se queremos de fato um Estado Social, e, por fim, a superação desta ordem societária, não se pode esquecer que a organização das pessoas deve ser a base para a atuação e luta por um fim comum, sem se desconsiderar a disputa fundamentada na luta de classes.

O Serviço Social, como uma das profissões que atua no campo da infância e da adolescência, pode estimular a organização coletiva em prol da defesa de direitos a partir do debate crítico e da capacidade de indignação com as injustiças e mazelas sociais que tendem a fazer com que um homem subjugue o outro pelas relações desiguais de poder, tal como, ao longo deste trabalho, pôde-se verificar na questão do trato à infância e adolescência.

Espera-se que com a realização desta pesquisa e com as reflexões até aqui efetuadas possamos ter contribuído com o debate sobre a política de atendimento que rege a política de atendimento ao adolescente em conflito com a lei, em especial a aplicação da liberdade assistida.

Tem-se a noção também de que este trabalho trata-se de um produto provisório, pois integra a historicidade do processo social e da construção teórica. Sua natureza, sobretudo exploratória, tentou proporcionar maior familiaridade com o problema, com vistas a torná-lo mais explícito (SUZUKI et al, 2009).

Aponta-se a necessidade de se implementar efetivamente a legislação do SINASE, bem como monitorar sua aplicação na prática, mediante processos democráticos e participativos, na busca do aperfeiçoamento de políticas práticas e justas que visem ampliar oportunidades e melhorar condições da vida de crianças e adolescentes. Acreditamos que o uso de mais pesquisas e pessoas experientes nessa área pode subsidiar esse processo no garante de direitos dessa parcela populacional. 


\section{REFERÊNCIAS BIBLIOGRÁFICAS}

ANDERSON, Perry. Balanço do neoliberalismo. in: Pós-neoliberalismo: As políticas sociais e o Estado democrático.Vários autores. Editora Paz e Terra. $8^{a}$ Edição. Rio de Janeiro, 2008.

ARANTES, Esther Maria de Magalhães. Rostos de crianças no Brasil. In: RIZINI, Irene; PILOTTI, Francisco (Orgs.). A arte de governar crianças. A história das políticas sociais, da legislação e da assistência à infância no Brasil. Editora Cortez, segunda edição revista. São Paulo, 2009, p.153-202.

BEHRING, Elaine Rossetti, BOSCHETTI, Ivanete. Política Social: Fundamentos e história. Cortez Editora. $3^{a}$ Edição. Volume 2. Biblioteca Básica de Serviço Social. São Paulo, 2007.

BRASIL, Lei $\mathbf{n}^{\circ}$ 8069. Dispõe sobre o Estatuto da Criança e do Adolescente e dá outras providências, 1990.

BRASIL. Código de ética profissional dos assistentes sociais. 1993. Disponível em: < http://www.cfess.org.br/arquivos/CEP_1993.pdf>. Último acesso em 21/08/2010.

BRASIL. Constituição Federal. Brasil,1988.

BRASIL. Estatuto da Criança e do Adolescente. Lei Federal 8.069, de 13 de julho de 1990. Brasília: Secretaria de Estado dos Direitos Humanos, Departamento da Criança e do Adolescente, 2002.

BRASIL. Sistema Nacional de Atendimento Socioeducativo - SINASE. $2^{\text {a }}$ Edição. Publicada pelo FNDCA. Brasília, Dezembro de 2009.

COUTINHO, Carlos Nelson. Gramsci: um estudo sobre o pensamento político. Capítulos V e IX. Rio de Janeiro: Civilização brasileira, 1999

DANTAS, Maria Francisca Máximo; NASCIMENTO, Juliana Maria do; SILVA, Julian Kelly Dantas da. Neoliberalismo e "Reforma" do Estado: breves considerações 
acerca da expansão do "terceiro setor" e do (des)financiamento das Políticas Sociais. Universidade Federal do Rio Grande do Norte,Universidade Esadual da Paraíba. Trabalho apresentado no XIII Congresso Brasileiro de Assistentes Sociais. Brasília, 31 de julho a 05 de agosto de 2010.

DUARTE, Janaína Lopes do. A funcionalidade do terceiro setor e das ongs no capitalismo contemporâneo: o debate sobre sociedade civil e função social. Revista Libertas on Line. vol. 2 n. 2, p.52-76. Juiz de Fora, 2008.

FALEIROS, Eva Teresinha Silveira. A criança e o adolescente. Objetos sem valor no Brasil Colônia e no Império. In: RIZINI, Irene; PILOTTI, Francisco (Orgs.). A arte de governar crianças. A história das políticas sociais, da legislação e da assistência à infância no Brasil. Editora Cortez, segunda edição revista. São Paulo, 2009, p.203-222.

FALEIROS, Vicente de Paula. Infância e processo político no Brasil. In: RIZINI, Irene; PILOTTI, Francisco (Orgs.). A arte de governar crianças. A história das políticas sociais, da legislação e da assistência à infância no Brasil. Editora Cortez, segunda edição revista. São Paulo, 2009, p.33-96.

FERNANDES, Véra Maria Mothé. O adolescente infrator e a Liberdade Assistida: Um fenômeno Sócio-jurídico. CBCISS Editora.Rio de Janeiro, 1998.

FUCHS, Andrea Márcia Santiago Lohmeyer. Telhado de vidro: as intermitências do atendimento socioeducativo de adolescentes em semiliberdade. (Análise nacional no período de 2004-2008). 2009. Tese (Doutorado em Política Social). Universidade de Brasília, Brasília, 2009.

GIUSTINA, Joacir Della Pe. Medidas socioeducativas em meio aberto: Prestação de Serviços à comunidade e Liberdade Assistida. In: Políticas Públicas e estratégias de Atendimento ao adolescente em conflito com a lei. Coleção Garantia de Direitos. Série Subsídios. Volume 2. Ministério da Justiça, 1998.

IAMAMOTO, Marilda Villela. A Questão Social No Capitalismo. In Temporalis. Associação brasileira de Ensino e Pesquisa em Serviço Social. Ano 2, n.3. Brasília, 2001. 
MACIEL, Kátia Regina F.L.Andrade. Curso de Direito da Criança e do Adolescente: Aspectos teóricos e práticos. $4^{\text {a }}$ Edição. Lumen Juris Editora. Rio de Janeiro, 2010 MARTINELli, Maria Lúcia (org.). Pesquisa Qualitativa: Um instigante desafio. Núcleo de Estudos e Pesquisas sobre identidade - NEPI. Veras Editora. São Paulo, 1999.

MINAYO, Maria Cecília de Souza (org.). Pesquisa Social: Teoria, Método e criatividade. 23 ${ }^{\text {a }}$ Edição. Editora Vozes. Petrópolis, 2004.

MONTAÑO, Carlos. Terceiro Setor e Questão Social: Crítica ao padrão emergente de intervenção social. $5^{\text {a }}$ edição. Cortez Editora. São Paulo, 2008.

NETTO, José Paulo. A Construção do Projeto Ético Político do Serviço Social. 1999. Disponível em 〈http://www.fnepas.org.br/pdf/servico_social_saude/texto2-1.pdf>. Último acesso em 20/08/2010.

NETTO, José Paulo. Capitalismo Monopolista e Serviço Social. Cortez Editora. $4^{\text {a }}$ edição. São Paulo, 2005.

OLIVA, Jimena Cristina Gomes Aranda; KAUCHAKJE, Samira. As políticas sociais públicas e os novos sujeitos de direitos: crianças e adolescentes. Revista Katálisys. Florianópolis v. 12 n. 1 p. 22-31 jan./jun. 2009.

PEREIRA, Potyara A. P. Do Estado Social ao Estado anti-social. In:Política social, Trabalho e Democracia em questão. Política Social - 4. Universidade de Brasília, Programa de Pós-Graduação em Política Social. Departamento de Serviço Social. Brasilia, 2009.

PEREIRA, Potyara. Questão Social e Serviço Social. In Temporalis. Associação brasileira de Ensino e Pesquisa em Serviço Social. Ano 2, n.3. Brasília, 2001.

PRIORE, Mary Del. O papel branco, a infância e os jesuítas na Colônia. In: PRIORE, Mary Del (org.). História da criança no Brasil. Editora Contexto. São Paulo, 1991, p.10-27. 
RIZZINI, Irene. Crianças e menores: do pátrio poder ao pátrio dever. Um histórico da legislação para a infância no Brasil. In: RIZINI, Irene; PILOTTI, Francisco (Orgs.). A arte de governar crianças. A história das políticas sociais, da legislação e da assistência à infância no Brasil. Editora Cortez, segunda edição revista. São Paulo, 2009, p.97-149.

RIZZINI, Irene. O Século Perdido: Raízes Históricas das Políticas Públicas para a Infância no Brasil. $2^{a}$ Edição Revista. Cortez Editora. São Paulo, 2008.

RIZZINI, Irene; PILOTTI Francisco (orgs.). A arte de governar crianças: A história das políticas sociais, da legislação e da assistência à infância no Brasil. Editora Cortez, segunda edição revista. São Paulo, 2009.

RIZZINI, Irene; RIZZINI, Irma. A institucionalização de crianças no Brasil: Percurso histórico e desafios do presente. $2^{\mathrm{a}}$ Edição. Editora PUC-RIO; São Paulo:Edições Loyola, 2004.

RIZZINI, Irma. Menores desvalidos e menores transviados: a trajetória da assistência pública até a Era Vargas. In: RIZINI, Irene; PILOTTI, Francisco (Orgs.). A arte de governar crianças. A história das políticas sociais, da legislação e da assistência à infância no Brasil. Editora Cortez, segunda edição revista. São Paulo, 200, p.225-286.

SILVA, Marcus Vinícius Lopes da, SILVA Paula Frassinetti Costa da. O perfil social dos jovens atendidos pela SEMSE em 2000. Vara da Infância e da Juventude VIJ/DF. Seção de Medidas Socioeducativas-SEMSE. Brasília, 2000.

SORIANO, Raúl Rojas. Manual de Pesquisa Social. Editora Vozes. Petrópolis, 2004.

TEJADAS, Silvia da. Juventude o ato infracional: As múlitiplas determinações da reincidência. ediPUCRS editora. Porto Alegre, 2008.

TORRES, Celia; FILHO, Rodrigo de Souza e MORGADO, Rosana. Política da Infancia e Juventude e Servico Social. Juiz de Fora: Libertas, 2006. 
TÔRRES, Raimunda Célia; FILHO, Rodrigo de Souza; MORGADO, Rosana. Instâncias e mecanismos jurídico-sociais do ECA: Desafios ao Assistente Social. s.l.n.

VERONESE, Josiane Rose Petry, RODRIGUES, Walkíria Machado. A figura da criança e do adolescente no contexto social: de vítimas a autores de ato infracional. In: VERONESE, Josiane Rose Petry, SOUZA, Marli Palma, MIOTO, Regina Célia Tamaso. Infância e adolescência, o conflito com a lei: Algumas discussões. Editora fundação BOITEUX. Florianópolis, 2001.

VERONESE, Josiane Rose Petry, SOUZA, Marli Palma, MIOTO, Regina Célia Tamaso. Infância e adolescência, o conflito com a lei: Algumas discussões. Editora fundação BOITEUX. Florianópolis, 2001.

VOGEL, Arno. Do Estado ao Estatuto. Propostas e vicissitudes da política de atendimento à infância e adolescência no Brasil contemporâneo. In: RIZINI, Irene; PILOTTI, Francisco (Orgs.). A arte de governar crianças. A história das políticas sociais, da legislação e da assistência à infância no Brasil. Editora Cortez, segunda edição revista. São Paulo, 2009, p.287-321.

VOLPI, MÁRIO. O adolescente e o ato infracional. $2^{\mathrm{a}}$ edição. Cortez Editora. São Paulo, 1997.

WACQUANT, Loïc. Punir os pobres: A nova gestão da miséria nos Estados Unidos [A onda punitiva]. $3^{a}$ edição revista e ampliada. Instituto Carioca de criminologia. Editora Revan. Rio de Janeiro, 2007. 